\title{
Marbury, Section 13, and the Original Jurisdiction of the Supreme Court
}

\author{
Akhil Reed Amar $\dagger$
}

In this year marking the Bicentennial of the Judiciary Act of 1789 , and in a symposium designed to commemorate that Act, it might seem perverse, if not downright gauche, to begin by reminding the reader that $\S 13$ of this Act was the only congressional provision held unconstitutional by the Supreme Court for the first third of our Constitution's history. (The case, of course, was Marbury $v$ Madison. ${ }^{1}$ ) I nevertheless begin this way because I believe that a careful re-examination of the narrow constitutional issues raised by $\S 13$ will yield important insights into larger and much debated issues of constitutional law. And the icing on the (200th birthday) cake is that such a re-examination will acquit $\S 13$ of the Marbury Court's charge of unconstitutionality-surely a fitting message to deliver on this celebratory occasion (even though it raises some problems for me about what I shall be able to write without perversity or gaucherie fourteen years hence, on the Bicentennial of Marbury itself). ${ }^{2}$

A brief summary of the questions that I shall pose, and the answers that I shall offer, is in order at the outset. After a broad

$\dagger$ Associate Professor, Yale Law School. B.A., 1980, Yale University; J.D., 1984, Yale Law School. I thank Bruce Ackerman, Vik Amar, Willy Fletcher, Jack Goldsmith, Paul Kahn, Larry Lessig, Mike Paulsen, Mike Rappaport, and John Siegel for their helpful comments on earlier versions of this essay. I also give special thanks to Jill Pryor and Gene Coakley for their research assistance, and their smiles.

This essay is dedicated to the memory of Paul M. Bator. I am not sure that Professor Bator would have agreed with all my arguments here, hut I am sure that he would have encouraged me to add my voice to the scholarly debate, as he did four years ago when I was deciding whether to enter the field of federal jurisdiction. He was a man of shining decency and true graciousness, and I feel privileged to have known him.

15 US (1 Cranch) 137 (1803).

2 Jesting aside, the bulk of my analysis is supportive of the Marbury Court. Although I shall argue that the Court erred in reading $\S 13$ as conferring original jurisdiction on the Supreme Court, that prong of my argument is hardly novel. Indeed, it simply echoes the dominant strain of modern academic commentary. See section II. However, much of this commentary goes further, challenging Marbury's holding that Article III prevents Congress from adding to the Supreme Court's original jurisdiction. On this constitutional issue, I shall attempt to defend the Marbury Court against its modern critics. See section III. See also section I (discussing other issues raised by Marbury). 
brush sketch of Marbury's overall legacy for current law, I shall ask, first, whether $\S 13$ attempted to confer original jurisdiction on the Supreme Court beyond the confines of "all Cases affecting Ambassadors, other public Ministers and Consuls, and those in which a State shall be Party." I shall argue that it did not. But if $\S 13$ had attempted to do so, there would arise a second question, namely does Congress have constitutional authority to extend original jurisdiction beyond the above quoted Article III catalogue? I shall argue that Congress does not have such authority, and that the language of Article III delimits the maximum amount of original jurisdiction that the Supreme Court may exercise. This conclusion raises a third question: if Congress may not add to the Supreme Court's original jurisdiction, may Congress take away any of the Supreme Court's original jurisdiction? I shall argue that Congress has no authority to deprive the Supreme Court of original jurisdiction over "all Cases affecting Ambassadors, other public Ministers and Consuls"4 but that Congress does have authority, under the "necessary and proper"s clause, to reduce or even to eliminate the Supreme Court's original jurisdiction over lawsuits "in which a State shall be Party." This conclusion in turn leads to a fourth and final question: does the Article III language about lawsuits "in which a State shall be Party" mean to include any suit in which a state is a litigant, or is the language rather meant to refer only to those lawsuits in which Article III jurisdiction is premised on the fact that a state is a party? I shall argue that, in context, the latter reflects a better reading of Article III. The "state party" language of Article III's Original Jurisdiction Clause refers only to three diversity-type controversies in the Article III jurisdictional menu, namely "Controversies between two or more States;--between a State and Citizens of another State; . . . and between a State ... and foreign States, Citizens or subjects.""

In the course of reaching these conclusions about the Supreme Court's original jurisdiction, I hope to do more than just tidy up a messy and rather technical corner of federal jurisdiction law. For once the Supreme Court's original jurisdiction is examined in context, larger themes of federal jurisdiction emerge. Thus, I shall attempt to illustrate how my reading of the Supreme Court's original

${ }^{3}$ US Const, Art III, § 2, cl 2.

4 Id (emphasis added).

- US Const, Art I, § 8, cl 18.

${ }^{6}$ US Const, Art III, § 2, cl 2.

7 US Const, Art III, § 2, cl 1. 
jurisdiction has important implications concerning: the scope and limits of Congress's power to strip the federal judiciary of jurisdiction; the basic vision of federalism underlying the Federalist Constitution; the best reading of the Eleventh Amendment; and the appropriate respective roles of text, history, structure, and doctrine in interpreting the Constitution.

\section{MARBURY'S LEGACY}

Before turning directly to the issues raised by $\S 13$, it is useful first to say a few words in passing about the case most prominently associated with that section, Marbury $v$ Madison. Marbury is a "classic" under any definition of the word, including Twain's-a work "which people praise and don't read." Thus, the case is perhaps most frequently cited, by the Supreme Court and by others who should know better, for the proposition that the Supreme Court is the "ultimate interpreter of the Constitution." Yet this proposition mangles the words of the opinion itself, which focus more on the "judicial department" (meaning all federal judges) than on "the Supreme Court,"10 and more on the competence of judges to adjudicate constitutional issues than on the uniqueness or supremacy of Article III adjudication vis-a-vis constitutional interpretations of coordinate branches of government. ${ }^{11}$ Thus, Marbury (properly read) does not imply that a President acts wrongfully when he pardons a person whose conviction the President deems unconstitutional, even though that conviction was previously upheld as constitutional by the Supreme Court. Similarly, a conscientious legislator does not violate the principles of Marbury or her own oath of office (on the contrary!) when she votes to repeal a law she thinks unconstitutional, even though she knows that the law has survived constitutional scrutiny by the Supreme Court. Yet in both of these cases, the Supreme Court is from one perspec-

${ }^{8}$ Mark Twain, Following the Equator: A Journey Around the World, ch 25 at 241 (American Publishing, 1897).

- See, for example, Powell v McCormack, 395 US 486, 549 (1969); United States v Nixon, 418 US 683, 704 (1974) (quoting Baker v Carr, 369 US 186, 211 (1962)); Alexander M. Bickel, The Least Dangerous Branch 1-14, 264 (Yale, 2d ed 1986).

${ }^{10}$ See, for example, Marbury, 5 US (1 Cranch) at 177-80, which speaks of "the judicial department" (i.e., federal judges) and "courts" (i.e., both federal and state tribunals).

1 "See, for example, id at 179-80, which notes that the Constitution constitutes "a rule for the government of courts, as well as of the legislature;" emphasizes the obligations created by the judicial oaths under Article VI to uphold the Constitution-oaths identical to those required of Congress and the President under the very same Article; and concludes the opinion by declaring that "courts as well as other departments, are bound by" the Constitution (emphasis altered). 
tive denied the last word as the "ultimate" interpreter of the relevant constitutional provision. ${ }^{12}$

If the exact words of the Marbury Court's discussion of judicial review are largely misunderstood by contemporary lawyers, the other issues raised by the case are largely ignored. There is a special irony here, for on the issue of judicial review, Marbury broke little new analytic ground, ${ }^{13}$ and was largely uncontroversial at the time. ${ }^{14}$ Many of the other issues decided by the Marbury case were far more urgent at the time of the decision, ${ }^{16}$ and remain critical today.

First, Marbury established not simply the power to review the constitutionality of congressional statutes in cases properly before the Court, but also the power to review the legality of actions (and inactions) of the executive branch. ${ }^{16}$ As Professor Monaghan has reminded us, Marbury thus stands as the cornerstone of modern administrative law. ${ }^{17}$ Monaghan notes that the Marbury Court's insistence on deciding legal questions of statutory interpretation de novo, and its refusal to defer to a contrary yet perhaps plausible interpretation rendered by the executive branch, have important implications for twentieth century administrative law cases such as NLRB $v$ Hearst Publications. ${ }^{18}$ Nor does Monaghan's analysis ex-

12 See Akhil Reed Amar, A Neo-Federalist View of Article III: Separating the Two Tiers of Federal Jurisdiction, 65 BU L Rev 205, 220 n 59, 222-24, 258 n 170, 263 n 191 (1985); Paul Brest, The Conscientious Legislator's Guide to Constitutional Interpretation, 27 Stan L Rev 585, 585-89 (1975); Paul Brest, Constitutional Citizenship, 34 Cleve St L Rev 175, 180-83 (1986); Paul Brest, Congress as Constitutional Decisionmaker and Its Power to Counter Judicial Doctrine, 21 Ga L Rev 57 (1986); Gerald Gunther, The Subtle Vices of the "Passive Virtues"-A Comment on Principle and Expediency in Judicial Review, 64 Colum L Rev 1, 25 n 155 (1964); William W. Van Alstyne, A Critical Guide to Marbury v Madison, 1969 Duke L J 1, 36-37; Note, the Senate and the Constitution, 97 Yale L J 1111 (1988).

${ }^{13}$ See, for example, Van Alstyne, 1969 Duke $L \mathrm{~J}$ at 38-45 (cited in note 12); David P. Currie, The Constitution in the Supreme Court: The Powers of the Federal Courts, 18011835, 49 U Chi L Rev 646, 655-56 (1982); Raoul Berger, Congress v The Supreme Court (Harvard, 1969).

14 See, for example, Charles Warren, 1 The Supreme Court in United States History, ch 5 (Little, Brown, 1926); Dumas Malone, 4 Jefferson and His Time: Jefferson the President First Term, 1801-1805, ch VIII at 151 (1970); Johnny C. Burris, Some Preliminary Thoughts on a Contextual Historical Theory for the Legitimacy of Judicial Review, 12 Okla City U L Rev 585, 626-41 (1987).

${ }^{15}$ See sources cited in note 14.

18 Marbury, 5 US (1 Cranch) at 154-73.

${ }_{17}$ Henry P. Monagban, Marbury and the Administrative State, 83 Colum L Rev 1 (1983).

${ }^{18} 322$ US 111 (1944). Monaghan, 83 Colum L Rev at 1-14, 25-31 (cited in note 17). For a more recent case raising similar issues, see Chevron U.S.A., Inc. $v$ Natural Resources Defense Council, Inc., 467 US 837 (1984). See generally Cass R. Sunstein, Constitutionalism 
haust the implications of Marbury for modern administrative law. To take just two other examples, the Marbury Court's willingness to review an executive decision not to act affirmatively (Madison declined to convey Marbury his commission) and to protect as a "vested" property right a government benefit created merely by statute has important (if often ignored) implications for such modern administrative law cases as Heckler $v$ Chaney ${ }^{19}$ and Goldberg $v$ Kelly. ${ }^{20}$

Second, the case obliged the Supreme Court to wrestle for the first time with the scope of implied Presidential powers-in particular, the asserted powers to remove officers ${ }^{21}$ and to invoke executive privilege. ${ }^{22}$ These issues, of course, have loomed large in our own time, lying at the heart of constitutional debates over independent agencies, ${ }^{23}$ special prosecutors, ${ }^{24}$ the Nixon tapes, ${ }^{25}$ and the Iran-Contra affair, ${ }^{26}$ to name just a few examples.

Third, the Marbury Court invoked the traditional legal maxim ubi jus, ibi remedium ("where there is a legal right, there is also a legal remedy"27) in order to fashion judicial relief for a violation of a statute, even though that statute created no express private right of action, ${ }^{28}$ and even though the imphed right to a commission was a "new property" right created by statute rather than an "old property" right created by the pre-existing (that is, pre-statute) common law. ${ }^{29}$ The key remedial principles of Marbury have un-

After the New Deal, 101 Harv L Rev 421, 463-69 (1987).

10470 US 821 (1985). See generally Cass R. Sunstein, Reviewing Agency Inaction After Heckler v Chaney, 52 U Chi L Rev 653 (1985).

${ }^{20} 397$ US 254 (1970); see also Charles A. Reich, The New Property, 73 Yale L J 733 (1964); Cass R. Sunstein, Lochner's Legacy, 87 Colum L Rev 873 (1987).

${ }^{21}$ Marbury, 5 US (1 Cranch) at 157, 162 (simply asserting that "when the officer is not removable at the will of the executive, the appointment is not revocable, and cannot be annulled").

22 Id at 139, 141-45.

${ }^{23}$ See, for example, Note, In Defense of Administrative Agency Autonomy, 96 Yale L J 787 (1987); Note, Incorporation of Executive Agencies into the Executive Branch, 94 Yale L J 1766 (1985).

${ }^{24}$ See, for example, Morrison v Olson, 108 S Ct 2597 (1988).

${ }^{23}$ See, for example, United States $v$ Nixon, 418 US 683 (1974).

${ }^{28}$ See generally Harold Hongju Koh, A Power Shared: The National Security Constitution After the Iran-Contra Affair (Yale, forthcoming 1990).

${ }^{27}$ Marbury, 5 US (1 Cranch) at 163. See also Akhil Reed Amar, Of Sovereignty and Federalism, 96 Yale L J 1425, 1484-94 (1987).

${ }^{28}$ See Marbury, 5 US (1 Cranch) at 172 ("It is true that the mandamus, now moved for, is not for the performance of an act expressly enjoined by statute").

20 See generally note 20; Alfred Hill, Constitutional Remedies, 69 Colum L Rev 1109 (1969); California v Sierra Club, 451 US 287, 299-301 (1981) (Stevens concurring). Marbury thus granted "standing" to a "beneficiary" of a statutory scheme. Compare Sunstein, 101 Harv L Rev at 474-75 (cited in note 18). 
derlain such modern era cases as Bivens $v$ Six Unknown Federal Agents ${ }^{30}$ in which the Court inferred a private cause of action for damages directly under the Constitution; Ex Parte Young, ${ }^{31}$ in which the Court inferred a private cause of action for injunctive relief directly under the Constitution; and J.I. Case Co. v Borak, ${ }^{32}$ in which the Court fashioned a private right of action for damages for violation of a congressional statute. The precise scope of each of these modern cases is currently in some question, with dramatic Supreme Court movement in recent years away from Borak, ${ }^{33}$ and modest retrenchment in the Bivens and Young contexts. ${ }^{34}$

Fourth, the Marbury Court went beyond simply establishing the power to review actions of Congress and the President, and to fashion remedies for violations of law; the Court also claimed the power to assert personal jurisdiction over, and order coercive remedies directly against, officers of the coordinate branches as proper defendants in a lawsuit. ${ }^{35}$ This holding, of course, has had obvious implications for such landmark cases as Youngstown $v$ Sawyer ${ }^{36}$ Powell $v$ McCormack, ${ }^{37}$ Bivens, and United States $v$ Nixon. ${ }^{38}$

so 403 US 388 (1971). See Amar, 96 Yale L J at 1507-09 (cited in note 27).

${ }^{31} 209$ US 123 (1908). See Amar, 96 Yale L J at 1479 n 218, 1507-08 \& n 321 (cited in note 27$)$.

${ }^{32} 377$ US 426 (1964).

${ }^{33}$ See, for example, Cannon v University of Chicago, 441 US 677 (1979). For a good general discussion of the recent cases, see Paul M. Bator, et al, Hart and Wechsler's The Federal Courts and the Federal System at 945-50 (Foundation, 3d ed 1988) ("Hart \& Wechsler").

34 Cases wrestling with the scope of Bivens include Chappell $v$ Wallace, 462 US 296 (1983); Bush v Lucas, 462 US 367 (1983); Nixon v Fitzgerald, 457 US 731 (1982); Carlson v Green, 446 US 14 (1980); and Davis v Passman, 442 US 228 (1979). Cases exploring (and cutting back) the scope of Young include Pennhurst State School \& Hosp. v Halderman, 465 US 89 (1984); Alabama v Pugh, 438 US 781 (1978) (per curiam); and Edelman v Jordan, 415 US 651 (1974).

ss Marbury, 5 US (1 Cranch) at 169-73. Judicial review as such need not necessarily entail that government officials must be suable as parties defendant in either their individual or official capacity. Many lawsuits between purely private parties can furnish the occasion for judicial review-as when an ordinary assumpsit action by a creditor against a debtor obliges a court to decide whether a congressional statute making paper money legal tender is constitutionally valid. Compare Alexis De Tocqueville, Democracy in America 10607 (Knopf, Bradley ed, 1945).

${ }^{38} 343$ US 579 (1952).

37 395 US 486 (1969). Powell can in many ways be seen as the modern Marbury. A putative office-holder of the United States brings suit in an Article III court for a writ of mandamus claiming he has been wrongfully denied his office by a coordinate branch of the federal government. In both cases, both the denial of office and the lawsuit are the subject of intense political scrutiny. In both cases, plaintiff sues as defendant an officer of a coordinate branch who claims immunity from suit (in Marbury, implied executive immunity; in Powell, legislative immunity under the "speech and debate" clause). Powell, 395 at 501-06. In both cases, the Court emphatically rejects blanket immunity, affirms its power to issue a 
Thus, Marbury is far more than simply a case cementing the doctrine of judicial review. Indeed from one (perhaps perverse) vantage point, it is equally fitting to see Marbury as the granddaddy of each of the five major modern doctrines limiting Supreme Court judicial review.

Consider first the set of subdoctrines-ripeness, mootness, standing, and so on-associated with the "case" or "controversy" requirements of Article III. Judicial review cannot occur in the abstract, but only in the course of deciding a properly framed legal "case" that clears all subdoctrinal thresholds. Yet these thresholds are themselves rooted in language from Marbury portraying judicial review as simply the incidental byproduct of applying rules to "particular cases .... [I]f both the law and the constitution apply to a particular case, . . . the court must determine which of these confiicting rules governs the case." 39 Second and related is the doc-

remedy against a subordinate official in the coordinate branch, and avoids reaching the question whether the head of that branch-the President or the Speaker of the House-is amenable to suit. Id. In both cases, the Court affirms that the case is legal and not political, and thus fit for judicial resolution. Id at 518-49. And in both cases, the Court on the merits rebukes a coordinate branch for its wrongful withholding of the office. Yet in neither case does a coercive remedy actually issue; both cases result simply in long declaratory judgments, and remands (in Marbury, de facto; in Powell, de jure) to other courts. Id at $\mathbf{5 5 0 .}$ The two opinions of the Court present classic models of interpretive argument authored by perbaps the two greatest Chief Justices in our nation's history. (Marbury was Chief Justice Marshall's first major constitutional opinion for the Court, and Powell was Chief Justice Warren's last, along with Kramer v Union Free School District No. 15, 395 US 621 (1969), handed down on the same day.) Ironically, Powell cites to Marbury only twice, and with uncharacteristic sloppiness. See Powell, 395 US at 549 ("it is the responsibility of this Court to act as the ultimate interpreter of the Constitution") (citing Marbury). Compare text at note 9. For a somewhat different perspective on the relationship between Powell and Marbury, see Morton Gitelman, Comments on Powell v. McCormack, 17 UCLA L Rev 160 (1969).

${ }^{38} 418$ US 683 (1974).

s2 Marbury, 5 US ( 1 Cranch) at 178 (emphasis added). Even under this passage's narrow case-centered conception of judicial review, a strong argument can be made that the current contours of subdoctrines such as ripeness, mootness, standing, and the like have created unnecessary and unjustified obstacles to federal jurisdiction. See Akhil Reed Amar, Law Story, 102 Harv L Rev 688, 717-19 (1989). But more importantly, this passage's narrow view of judicial review is tempered not only by other language in Marbury presenting judicial review as a more free floating structural check on the legislature, 5 US (1 Cranch) at 178 , but also by the very fabric of the entire Marbury opinion, in which the Court reached out to decide a vast number of constitutional issues that it did not "of necessity" need to reach to decide the "particular case" at hand. Amar, 102 Harv L Rev at 702 n 69.

Professor Van Alstyne has hypothesized that the Marbury Court may well have deemed it necessary to decide all the questions it did in obedience to the principle of judicial restraint, later canonized in Justice Brandeis's classic concurrence in Ashwander v TVA, 297 US 288, 341, 345-348 (1936) (Brandeis concurring), that wherever possible, courts should resolve cases on nonconstitutional grounds and thus avoid the peculiar delicacy of invalidating Acts of Congress. Van Alstyne, 1969 Duke $\mathrm{L} \mathrm{J}$ at 7 (cited in note 12). There are several 
trine that federal courts cannot exercise judicial review over "political questions." Here too, the roots of this doctrine are to be found in explicit language of Marbury itself. ${ }^{40}$

A third important current constraint on the principle of judicial review derives from concepts of sovereign and executive immunity-concepts that have been deployed on countless occasions to defeat federal jurisdiction and frustrate the remedial imperative even when the rights at stake are of constitutional magnitude. ${ }^{41}$ Despite Marbury's firm repudiation of any notion of blanket executive immunity from suit, the Court avoided reaching the question whether the President himself, or more broadly still, the United States itself, could be sued if necessary to provide a full legal remedy for the violation of a legal right..2 Notwithstanding their per-

problems with this hypothesis. First, the Marbury Court never offers this-or any other-excuse for inverting the traditional practice of deciding jurisdictional questions at the outset. See, for example, Ex parte McCardle, 74 US (7 Wall) 506, 514 (1869). This practice appears to have been well established by the early 1800 s. See Warren, 1 The Supreme Court, ch 5 at 249-51 (cited in note 14) (chronicling contemporary criticism of Marbury for deciding the merits of the case when the Court had no jurisdiction); id at 244-45 (quoting 1823 letter of Thomas Jefferson to Judge William Johnson that criticizes Marshall for his "gratuitous" "obiter dissertation" "travelling out of his case"); Wilson v Mason, 5 US (1 Cranch) 45, 91-92 (1801) (Marshall for the Court) (deciding jurisdiction at outset); United States v More, 7 US (3 Cranch) 159, 172-74 (1805) (Marshall for the Court) (similar); Edward S. Corwin, Marbury v Madison and the Doctrine of Judicial Review, 12 Mich L Rev 538, 539 (1914) (citing these and other cases). Second, Marshall's inversion of issues does not of course avoid reaching the constitutionality of $\S 13$, and along his circuitous path he ends up deciding many other issues of constitutional "delicacy"-hardly a model of the vision of restraint conjured up by Justice Brandeis. What's more, had a vision of restraint like the one put forth in Ashwander been animating the opinion, the Court could have easily avoided holding $\S 13$ unconstitutional by giving the Act a narrowing-indeed its most plausible (see section II, below)-construction. Compare Mossman $v$ Higginson, 4 US (4 Dall) 12,14 (1800) (giving $\S 11$ of the Judiciary Act of 1789 a narrowing construction); Hodgson v Bowerbank, 9 US (5 Cranch) 303 (1809) (Marshall for the Court) (similar). See generally Dennis J. Mahoney, A Historical Note on Hodgson v Bowerbank, 49 U Chi L Rev 725 (1982). Finally, the Ashwander restraint philosophy seems most appropriate in judicial settings after jurisdiction has been established, rather than in those settings in which jurisdiction is itself at issue.

10 See Marbury, 5 US (1 Cranch) at 165-66, 170. As with the other justiciability doctrines discussed in note 39 , acceptance of the idea that federal courts should not decide "political questions" in no way entails accepting the current contours of the so-called political question doctrine. For a convincing critique of current doctrine, see Louis Henkin, Is There A "Political Question" Doctrine?, 85 Yale L J 597 (1976). Professor Currie has argued persuasively that it makes little sense to read Chief Justice Marshall's language about political questions as cutting into, rather than simply marking the boundary of, the "province and duty of the judicial department to say what the law is" and to provide legal remedies for violations of legal right. Currie, $49 \mathrm{U}$ Chi L Rev at 652 n 46 (cited in note 13).

1 See Amar, 96 Yale L J at 1426, 1484-92 (cited in note 27). Even before Marbury, the Court had begun to grapple with these issues. See Chisholm v Georgia, 2 US (2 Dall) 419 (1793).

${ }^{12}$ Former attorney general Charles Lee, as counsel for Marbury, took pains to empha- 
version of the animating spirit of Marbury, various forms of executive and sovereign immunity subsequently slithered into the halls of justice through cracks left open by Marshall's opinion.

The fourth threat to judicial review today comes from socalled "legislative" (or "Article I") courts. Officials of these "courts" lack the salary and tenure guarantees, and other status attributes, of Article III judges. Yet, they seem to perform functions-applying law to specific facts and processing "cases"-that lie close to the core of the "judicial power of the United States." What limits are there on the power of the political branches to shift adjudication (and the concomitant power of judicial review) from constitutionally insulated Article III judges to more politically dependent "Article I" courts? ${ }^{43}$ The Supreme Court has grappled with this question on no fewer than four occasions in the $1980 \mathrm{~s},{ }^{44}$ but the issue is hardly a new one; once again, the first case in this line is Marbury. William Marbury claimed to hold office as a "justice of the peace in the district of Columbia." As According to his lawyer Charles Lee, all such justices were "judicial officers" and

size at oral argument that "[t]he President is no party to this case." Marbury, 5 US (1 Cranch) at 141. Later he conceded that mandamus could never run against the President, who "is not amenable to any court of judicature for the exercise of his high functions." Id at 149. The Marbury Court maintained a pointed silence on this precise issue, although it used language which, if taken literally, implied Presidential suahility. Id at 165 (focusing on "nature of the act" in question and implying that only kings can claim absolute immunity from suit); id at 166-67 (distinguishing hetween legal duties and political discretion); id at 170 ("It is not by the office of the person to whom the writ is directed, but the nature of the thing to be done that the propriety or impropriety of issuing a mandamus, is to he determined.").

Elsewhere the Marbury Court acknowledged the right of executive officers to invoke the general immunity against compelled self-incrimination enjoyed by all citizens. Id at 144 .

${ }^{43} \mathrm{My}$ own answer to this question would insist that, strictly speaking, "legislative courts" are neither legislative nor courts; rather, they are executive agencies. Nonetheless they may function somewhat like courts. Indeed, a plausible argument can be made that their "judges," though executive officers, may be insulated from plenary Presidential removal power. See Note, 96 Yale L J at 793-95, 798-808 (cited in note 23) (distinguishing between "Presidential" and "executive" powers). These executive agencies can process "cases" and hear "appeals," since Congress can generally require administrative exhaustion before allowing recourse to a real-that is, an Article III-court. Still their final decisions must generally be reviewable by Article III tribunals to guarantee conformity with federal law, as expounded by the Article III judiciary. Compare Northern Pipeline Construction Co. $v$ Marathon Pipe Line Co., 458 US 50, 69-70 n 23 (1982) (plurality opinion). For a sensitive analysis of these issues, see Richard H. Fallon, Jr., Of Legislative Courts, Administrative Agencies, and Article III, 101 Harv L Rev 916 (1988).

46 See Commodity Future Trading Comm'n v Schor, 478 US 833 (1986); Thomas v Union Carbide Agricultural Products Co., 473 US 568 (1985); Northern Pipeline Construction Co. v Marathon Pipe Line Co., 458 US 50 (1982); United States v Raddatz, 447 US 667 (1980).

4s Marbury, 5 US (1 Cranch) at 151. 
were "authorized to hold courts" and enter "judgments."46 Marbury, Lee claimed, was a "judge" holding office "under the Constitution," and exercising "part of the judicial power of the United States." 47 Yet the statute creating Marbury's office did not recognize his status as an Article III judge, with tenure "during good behavior." 48 On the contrary, it explicitly limited his commission to a five-year term. ${ }^{48}$ If Marbury was indeed a judicial officer exercising part of "the judicial power of the United States" how could Congress deny him Article III status? ${ }^{50}$ Alternatively, if Marbury was not a judicial officer, why should he be immunized from Presidential removal? Chief Justice Marshall's opinion nowhere answered this riddle and thus left unplugged yet another hole in the doctrine of Article III judicial review-a hole of uncertain and perhaps gargantuan proportions.

Fifth, and most important for the main set of questions discussed below, Marbury's holding opens the door for Congress to strip the Supreme Court of jurisdiction in controversial constitutional areas where Congress is dissatisfied with how the Court has exercised, or is likely to exercise, judicial review. For Marbury nowhere denies and, in fact, expressly states, that the Court's appellate jurisdiction is subject to "such exceptions as congress might make." Prior to Marbury, an argument could possibly have been made that Congress could exercise this "exception" power only by shifting a case from the Court's appellate to its original docket, thus leaving the Court with the inviolate authority to exercise judicial review in every case; under this argument, Congress would have authority only to prescribe the mode-the timing-of that exercise. ${ }^{22}$ Yet Marbury emphatically forecloses such an argument,

$46 \mathrm{Id}$.

47 Id.

48 US Const, Art III, § 1.

40 Marbury, 5 US (1 Cranch) at 151.

so One possible answer might be that the ordinary limitations of Article III do not bind Congress when it legislates for the territories. See American Insurance Co. $v$ Cantor, 26 US (1 Pet) 511, 545 (1828). This "territorial court" variant of the "legislative court" doctrine unravels into yet another possible loophole in judicial review-namely, the question whether and to what extent the Constitution applies extra-territorially. For an especially harsh-and harshly criticized-enlargement of this loophole, see Shaughnessy $v$ United States ex rel. Mezei, 345 US 206 (1953), and the ensuing criticism, Hart \& Wechsler at 415-19 (cited in note 33).

51 Marbury, 5 US (1 Cranch) at 175. See also United States $v$ More, 7 US (3 Cranch) 159, 170-74 (1805) (Marshall for the Court) (dismissing case raising constitutional questions for lack of appellate jurisdiction and explicitly basing dismissal on congressional power to make exceptions and regulations to Supreme Court's appellate jurisdiction).

\$2 For modern day defenses of this view, see Van Alstyne, 1969 Duke $L J$ at 33 (cited in 
for the Court holds not only that original jurisdiction need not be expanded when appellate jurisdiction is contracted, but indeed that original jurisdiction may never be expanded. ${ }^{53}$ The upshot, of course, is that any congressional exception to the Supreme Court's appellate jurisdiction takes cases away from the Court altogether, and thus effects an end run around Supreme Court judicial review.

Before we examine in detail whether the Marbury Court was correct in saying that Congress may never add to the Supreme Court's original jurisdiction, we must first ask whether the Court needed to reach that question at all. For the constitutional question only emerged once the Court had read $\S 13$ as purporting to extend original jurisdiction beyond the language of Article III to all cases involving mandamus against federal officials. Was this reading correct? I think not.

\section{First Question: Did Section 13 Purport to Confer Original Jurisdiction in Mandamus Cases?}

Section 13 is the only part of the Judiciary Act of 1789 that addresses the original jurisdiction of the Supreme Court. However, even a casual inspection of the entire section reveals that Supreme Court original jurisdiction is not the only thing addressed:

And be it further enacted, That the Supreme Court shall have exclusive jurisdiction of all controversies of a civil nature, where a state is a party, except between a state and its citizens; and except also between a state and citizens of other states, or aliens, in which latter case it shall have original but not exclusive jurisdiction. And shall have exclusively all such jurisdiction of suits or proceedings against ambassadors, or other public ministers, or their domestics, or domestic servants, as a court of law can have or exercise consistently with the law of nations; and original, but not exclusive jurisdiction of all suits brought by ambassadors, or other public ministers, or in which a consul, or vice consul, shall be a party. And the trial of issues in fact in the Supreme Court, in all actions at law against citizens of the United States, shall be by jury. The Supreme Court shall also have appellate jurisdiction from the

note 12); Robert N. Clinton, A Mandatory View of Federal Court Jurisdiction: A Guided Quest for the Original Understanding of Article III, 132 U Pa L Rev 741, 778, 793, 827 (1984). But see Amar, 65 BU L Rev at 214 \& $\mathrm{n} \mathrm{39,} 231 \mathrm{n} 88$ (cited in note 12); text at notes 104-25.

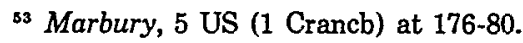


circuit courts and courts of the several states, in the cases herein after specially provided for; and shall have power to issue writs of prohibition to the district courts, when proceeding as courts of admiralty and maritime jurisdiction, and writs of mandamus, in cases warranted by the principles and usages of law, to any courts appointed, or persons holding office, under the authority of the United States. ${ }^{54}$

The Marbury Court never quotes this section in its entirety. Rather, it simply quotes the words after "power"ss (deleting without notation the words concerning writs of prohibition in admiralty jurisdiction) and notes that Madison, "being a person holding an office under the authority of the United States, is precisely within the letter of the description." "58 Then, without any further discussion or analysis, the Court concludes that this section's "words purport to confer and assign" to the Court original jurisdiction to adjudicate Marbury's suit against Madison, so that the suit will be barred only if "the law is unconstitutional."

As recent scholars have pointed out, however, two other readings of $\S 13$ are possible: ${ }^{58}$ first, that the final clauses of $\S 13$ concerned only appellate jurisdiction; second, that they did not attempt to confer any jurisdiction at all. Under the first, the language about power to issue writs of mandamus and prohibition would be confined to the appellate jurisdiction of the Supreme Court. This reading looks especially plausible at first since the clauses dealing with writs of prohibition and mandamus do not rest on their own syntactical bottom; rather, they are appended, via a semi-colon, to language explicitly directed only to the Supreme Court's appellate jurisdiction. ${ }^{69}$ But looks can be deceiving; as the very sentence I am now writing illustrates-and so too with the sentence before it-semi-colons often serve as substitutes for periods, separating distinct propositions. ${ }^{60}$

\footnotetext{
54 Judiciary Act of 1789 , ch $20, \S 13,1$ Stat $73,80-81$ (emphasis added).

Bs As we shall see below, "power" is a crucial word; its omission by the Marbury Court is revealing. See text at notes $67-80$.

se Marbury, 5 US (1 Cranch) at 173.

s7 Id.

${ }^{58}$ See, for example, Van Alstyne, 1969 Duke L J at 15 (cited in note 12); Currie, $49 \mathrm{U}$ Chi L Rev at 653 (cited in note 13).

${ }^{59}$ Professor Van Alstyne specifically notes this grammatical connection. Van Alstyne, 1969 Duke L J at 15 (cited in note 12).

${ }^{B 0}$ Although in $\S 13$ the clauses after the semi-colon refer back to the previous clause for their subject ("The Supreme Court"), the same is true of the sentence after the first period in $\S 13$, which refers back to the first sentence for its subject. For a similar textual analysis, see Akhil Reed Amar, Our Forgotten Constitution: A Bicentennial Comment, 97 Yale L J
} 
What's more, the notion that $\S 13$ provides for mandamus only in appellate cases runs into considerable technical difficulties. Although writs of mandamus issued against "courts appointed ... under the authority of the United States" seem to be quintessentially appellate in nature-mandamus is one of the classic modes by which an appellate court maintains control over an inferior tribunal-writs running directly against "persons holding [nonjudicial] office, under the authority of the United States" seem more characteristic of original jurisdiction. The Marbury Court itself makes this very point in a later passage analyzing Article III:

It is the essential criterion of appellate jurisdiction, that it revises and corrects the proceedings in a cause already instituted, and does not create that cause. Although, therefore, a mandamus may be directed to courts, yet to issue such a writ to an officer for delivery of a paper, is in effect the same as to sustain an original action for that paper, and therefore seems not to belong to appellate, but to original jurisdiction. ${ }^{61}$

Although Marshall did not invoke it, another section of the Judiciary Act lends support to his view that mandamus against nonjudicial officers almost always implicates original rather than appellate jurisdiction. In any suit originating in lower federal court and reaching the Supreme Court on a writ of error, $\S 24$ expressly provided that any execution (such as a writ of mandamus against a nonjudicial defendant) must issue from the lower court; the Supreme Court's appellate function was to issue orders to the court below, rather than to the defendant directly. ${ }^{62}$

Also illuminating is the language Congress used in amending $\S 13$ in light of Marbury. In lieu of the final clause after the semicolon, Congress provided:

Sec. 688 The Supreme Court shall have power to issue writs

281, 283 (1987) (draft Constitution of September 12, 1787 used periods after each enumeration of legislative power in Article I, $\S 8$; printed Constitution of September 18 used colons; parchment copy used semi-colons); id at 286 \& n 25 (cautioning against placing too much reliance on these fine points of punctuation).

1 Marbury, 5 US (1 Cranch) at 175-76.

62 Judiciary Act of $1789, \operatorname{ch} 20 \S 24,1$ Stat 73,85 . Although the Court later held that circuit courts generally could not issue mandamus against executive officers even in diversity suits properly within $\S 11$, see McClung $v$ Silliman, 19 US (6 Wheat) 598, 600-02 (1821), mandamus suits could be brought in the circuit court for the District of Columbia, Kendall $v$ United States ex rel Stokes, 37 US (12 Pet) 524, 615-26 (1838). Indeed, in light of the McClung Court's additional holding barring state court mandamus suits, all appellate mandamus cases coming to the Supreme Court would be governed by $\S 24$. McClung, 19 US (6 Wheat) at 603-05. 
of prohibition in the district courts, when proceeding as courts of admiralty and maritime jurisdiction; and writs of mandamus, in cases warranted by the principles and usages of law, to any courts appointed under the authority of the United States, or to persons holding office under the authority of the United States, where a State, or an embassador [sic], or other public minister, or a consul or vice-consul is a party. ${ }^{63}$

Not only does new language at the beginning of this passage separate it grammatically from words granting appellate jurisdiction (words which themselves were rewritten and placed in their own separate section), ${ }^{64}$ but new language at the end rather strongly suggests that the power to issue writs of mandamus against nonjudicial officers exists only where the Court is exercising original jurisdiction. ${ }^{65}$

Yet rejection of the "appellate jurisdiction" reading of the mandamus clause of $\S 13$ need not lead us by default to accept the Marbury Court's interpretation of the language; for there is a second, better, alternative to Marbury's reading. Unlike the first alternative, this second reading does not confine the mandamus clause to appellate jurisdiction; but unlike Marbury, this second reading does not view the clause as "confer[ring] and assign[ing]" original jurisdiction. Rather, the mandamus clause is best read as simply giving the Court remedial authority-for both original and appellate jurisdiction cases-after jurisdiction (whether original or appellate) has been independently established. ${ }^{66}$ Strictly speaking, the last clause does not add to or "confer" either original or appellate jurisdiction-it specifies a possible consequence of, rather than a basis for, jurisdiction.

Begin by noting that the language does not speak of "conferring jurisdiction" but of granting "power."67 Of course, taken alone, this textual tidbit is hardly dispositive. For example, Article III's language of "judicial power" surely subsumes subject matter

${ }^{63}$ Rev Stat, Title XIII, ch 11, § 688 at 127-28 (1878) (emphasis added).

64 Id $\S 690$ at 128.

Bs As with the language of the original Judiciary Act, the new language of this section is an unfortunately imprecise paraphrase of the original jurisdiction language of Article III itself. See Amar, 65 BU L Rev at 261 n 183, $264 \mathrm{n} 194$ (cited in note 12).

${ }^{68}$ For the provisions of the Judiciary Act establishing such independent bases for Supreme Court jurisdiction, see the first two sentences of $\S 13$ (original jurisdiction), and $\S \S 22$ (appellate jurisdiction over lower federal courts) and 25 (appellate jurisdiction over state courts).

${ }^{67}$ Van Alstyne, 1969 Duke L J at 15 (cited in note 12); Currie, $49 \mathrm{U}$ Chi L Rev at 653 (cited in note 13). 
jurisdiction to decide cases falling in certain enumerated categories. ${ }^{68}$ What is more suggestive, however, is that $\S 13$ nowhere else uses the word "power" to confer jurisdiction; rather, the word "jurisdiction" is itself used, no less than six times in all: five times to confer Supreme Court jurisdiction, and once in the very clause in question to refer to the lower courts' "admiralty and maritime jurisdiction." "69

Other sections of the Judiciary Act reveal a clear pattern. Nowhere else is the word "power" used to confer jurisdiction. Instead, the Act over and over again uses two words-"jurisdiction" and "cognizance." Thus $\S 9$, which establishes the jurisdiction of federal district courts, speaks five times of giving "cognizance" and once of giving "jurisdiction," to those courts over certain matters;" $\S 10$, establishing hybrid courts for geographically outlying districts in Kentucky and Maine uses the word "jurisdiction" three times; $;^{71} \S 11$ gives the circuit courts "cognizance" over certain sets of cases on three occasions, and speaks on a fourth occasion of the courts" "appellate jurisdiction."

Later sections of the Judiciary Act, however, do use the word "power":

Sec. 14. And be it further enacted, That all the before-

63 Amar, 65 BU L Rev at 233 (cited in note 12).

of The strongest textual arguments involve more than a simple fist-pounding insistence that a word in isolation be accorded its "plain meaning." Such "plain meaning" arguments from specific words are enhanced by looking to other parts of the same document that use the same word or different words. Thus, in an earlier essay in which I sought to establish the two-tiered nature of Article III jurisdiction, my textual argument sought to go beyond simple insistence that "shall" means "shall" and "all" means "all" by examining the contrast between the framers' use of "shall" and their use of "may," Amar, 65 BU L Rev at 212

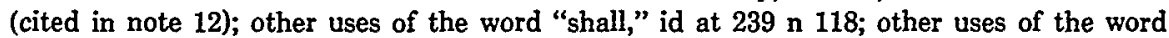
"all," id at 242; and the contrast between the use of the word "all" in some jurisdictional categories and the failure to use that word in others, id at 242 \& $n$ 122. In addition, I sought to root this textual claim in the context of broader reaching structural, historical, and doctrinal arguments. See generally Richard H. Fallon, Jr., A Constructive Coherence Theory of Constitutional Interpretation, $100 \mathrm{Harv}$ L Rev 1189 (1987). For other illustrations of this non-clause bound textual strategy, see Amar, $102 \mathrm{Harv}$ L Rev at 716-18 (cited in note 39) (discussing possible distinction between "cases" and "controversies"); text at notes 102-03 (discussing contrast between phrasing of Original and Appellate Jurisdiction Clauses of Article III); McCulloch v Maryland, 17 US (4 Wheat) 316, 414-15 (1816) (discussing contrast between "necessary and proper" clause of Article I, $\S 8$, and "absolutely necessary" clause of Art I, § 10); Akhil Reed Amar, Philadelphia Revisited: Amending the Constitution Outside Article V, 55 U Chi L Rev 1043 (1988) (noting a pattern in the Constitution's reference to "the people").

70 Judiciary Act of 1789 , ch $20, \S 9,1$ Stat 73, 76-77.

71 Judiciary Act of 1789 , ch $20, \S 10,1$ Stat $73,77-78$.

72 Judiciary Act of 1789 , ch $20, \S 11,1$ Stat 73, 78-79. 
mentioned courts of the United States, shall have power to issue writs of scire facias, habeas corpus, and all other writs not specially provided for by statute, which may be necessary for the exercise of their respective jurisdictions, . . . And that either of the justices of the supreme court, as well as judges of the district courts, shall have power to grant writs of habeas corpus....

Sec. 15. And be it further enacted, That all the said courts of the United States, shall have power ... . to require the parties to produce books or writings in their possession or power ....

Sec. 17. And be it further enacted, That all the said courts of the United States shall have power to grant new trials, .... and shall have power to impose and administer all necessary oaths or affirmations, and to punish by fine or imprisonment . . . all contempts of authority ... and to make and establish all necessary rules for the orderly conducting business. . . . .73

In each of these sections, it is clear from context that the Act is investing courts with certain authority if and when they have independently founded jurisdiction, based on earlier sections of the Act. Section 14, for example, tracks $\S 13$ in explicitly distinguishing between "power" to issue writs and "jurisdiction" over a case. "Jurisdiction" must be established first, and independently; "power" then follows, derivatively. Indeed, the Court in McIntire $v$ Wood ${ }^{74}$ explicitly held that $\S 14$-the precursor of today's All Writs Act $^{75}$-conferred no jurisdiction on circuit courts above and beyond the categories of "cognizance" and "jurisdiction" established by $\S 11 .{ }^{76}$ As Justice Johnson later noted in McClung $v$ Silliman ${ }^{77}$ which underscored and extended the McIntire holding, ${ }^{78}$

${ }^{73}$ Judiciary Act of 1789 , ch $20, \S \S 14,15,17,1$ Stat $73,81-83$ (emphasis added).

711 US (7 Cranch) 504 (1813).

${ }^{75} 28$ USC $\$ 1651$ (1982).

${ }^{76}$ McIntire, 11 US (7 Cranch) at 506.

7719 US (6 Wheat) 598 (1821).

78 The McClung Court's extension of the holding in McIntire was quite problematic. In McClung, the Court held that even when, unlike the situation in McIntire, a suit properly met the diversity standards of $\S 11$, circuit courts could not invoke $\S 14$ to issue writs of mandamus against executive officers. Judge Arnold is charitable when he says, "[i]t is hard to define the rationale of the case with precision." Richard S. Arnold, The Power of State Courts to Enjoin Federal Officers, 73 Yale L J 1385, 1392 (1964). A more accurate assessment would be that the Court offers no logical rationale for the extension. See David P. Currie, Federal Courts: Cases and Materials ch IV, $\$ 3$ at 510-11 (West, 3d ed 1982). 
any other reading would be pure bootstrap. ${ }^{79}$ This bootstrap would not only distort the purpose of $\S 14$; it would obviously violate Article III by giving federal courts jurisdiction whenever certain writs were sought, whether or not the underlying lawsuit fell within one of the nine categories of cases and controversies set forth in the jurisdictional menu of Article III, § 2. The obvious connections between the issues raised by the last clause of $\S 13$, and those raised by $\S 14$ are further strengthened by Professor Corwin's historical research demonstrating that the writs at stake in these two sections were seen as similar:

[I]n Common Law practice, in the light of which $\S 13$ was framed, the writ of mandamus was not, ordinarily at least, an instrument of obtaining jurisdiction by a court, even upon appeal, but like the writs of habeas corpus and injunction, was a remedy available from a court in the exercise of its standing jurisdiction. ${ }^{80}$

Thus, the overall structure of the Judiciary Act of 1789 seems to specify original and appellate jurisdiction as such, and to treat remedial power quite separately-a structural logic replicated in microcosm within $\S 13$, with its special focus on the Supreme Court.

Further evidence undermining the Marbury Court's reading of $\S 13$ comes from the Court's own reading of Article III. If, as the Marbury Court insisted, Article III plainly prohibited expanding the Court's original jurisdiction-and we shall see below that a strong argument can be made in support of this conclusion ${ }^{81}$-does it not make sense to think that the first Congress shared this view? Indeed, it is noteworthy that apart from the (at most, ambiguous) mandamus clause at issue, nowhere else in the Judiciary Act of 1789 , or in any subsequent Judiciary Act, ${ }^{82}$ did Congress attempt

79 19 US (6 Wheat) at 601-02.

${ }^{80}$ Corwin, 12 Mich L Rev at 541 (cited in note 39). In light of the general language of $\S$ 14, which covers both Supreme Court and lower federal courts, it might be asked why the last clause of $\S 13$ was necessary. Put another way, what remedial power does $\S 13$ add to the general remedial power conferred by $\S 14$ ? Two answers spring to mind. First, without express $\S 13$ language authorizing writs of prohibition against district courts, the Court might well have been limited under $\$ 14$ to issuing writs to circuit courts in admiralty cases, since the Court had no direct appellate review over district courts. Second, the fact that $\S 13$ explicitly mentions mandamus whereas $\S 14$ does not may itself be grounds for viewing mandamus as a truly exceptional writ not covered by the general language of $\S 14$. This seems a far more plausible argument for the holding of McClung $v$ Silliman, 19 US (6 Wheat) 598 (1821) than anything that the Court said. See note 78 (discussing McClung).

s2 See section III.

82 'Professors Bloch and Marcus have identified an "early draft" of the Judiciary Act of 
to extend the original jurisdiction of the Court beyond the boundaries laid down by Article III..$^{83}$

This last point can be turned around and used to support Marbury's constitutional holding: the fact that (once the mandamus clause is given its most sensible reading) Congress nowhere sought to add to the Court's original jurisdiction as laid out in Article III is itself modest evidence that Congress shared the Marbury Court's reading of that Article. In their rush to poke holes in the Marbury opinion-and the opinion does deserve a poke or two-modern scholars often want to have it both ways: they simultaneously criticize the Court for misconstruing $\S 13$ and for reading Article III in a way different from the first Congress (many of whose members had been key framers of the Constitution itself). ${ }^{84}$ Admittedly, we must note the following asymmetry. If Congress did attempt to extend original jurisdiction, such an attempt would necessarily mean that Congress (at least impliedly) rejected the notion that Article III delimited the maximum amount of Supreme Court original jurisdiction. Conversely, if Congress did not make such an attempt, it might mean only that Congress thought the attempt unwise or undesirable rather than unconstitutional. Nevertheless, the uniform pre-Marbury congressional practice, when

1801 that would have extended the original jurisdiction of the Supreme Court to a variety of contract and tort suits brought against the United States. Susan Low Bloch and Maeva Marcus, John Marshall's Selective Use of History in Marbury v Madison, 1986 Wis L Rev 301, 330. Moreover, John Marshall was a member of the committee that drafted the bill. Id. Professors Bloch and Marcus note that this provision was eventually "struck from the bill, but the legislative history nowhere suggests that any concern for constitutionality motivated the deletion." Id at 330. Yet as the authors themselves note on the same page, the records of Congress disclose only that a "lengthy debate" occurred when the motion to strike the provision was made. Id at $330 \mathrm{n} \mathrm{110.} \mathrm{When} \mathrm{it} \mathrm{was} \mathrm{finally} \mathrm{deleted,} \mathrm{no} \mathrm{debate} \mathrm{or} \mathrm{vote} \mathrm{was} \mathrm{re-}$ corded. Id. Thus, the legislative history also nowhere suggests that concern for constitutionality did not motivate the decision. What we are left with are the following facts:

(1) the proposal appeared only in an "early draft";

(2) the proposal was defeated after "lengthy debate";

(3) concern ahout constitutionality generally pervaded discussions in the early Congresses, especially when Judiciary Acts were involved. See generally H. Jefferson Powell, The Original Understanding of Original Intent, 98 Harv L Rev 885, 913, 940-41 (1985); Jonathan Elliot, 4 The Debates in the Several State Conventions on the Adoption of the Federal Constitution 327-554 (1836) ("Elliot's Debates"); and

(4) well hefore 1800 , numerous leaders had explicitly or impliedly argued that Article III marked the maximum amount of original jurisdiction that could be exercised by the Supreme Court. See text at notes 114-25.

These facts suggest that the "lengthy debate" may well have turned in part on concerns about constitutionality.

${ }^{83}$ But see note 151 (discussing circuit riding).

84 See, for example, Van Alstyne, 1969 Duke $\mathrm{L} J$ at 15-16, $32-33$ (cited in note 12); Bloch and Marcus, 1986 Wis L Rev at 320-21 \& nn 72, 74, and at 331-32 (cited in note 82). 
combined with the fact that no contemporary critics of Marbury took issue with its reading of Article III, does suggest the possibility of a general constitutional consensus. ${ }^{85}$

Before we take up this Article III question in more detail, it remains to ask two obvious questions: First, if the "remedial power" interpretation of $\S 13$ is so obviously the best one, why did Charles Lee bring suit in the Supreme Court instead of some other court? And why did the Marbury Court read $\S 13$ as it did?

In answer to the first question, it should be noted that on several occasions prior to Marbury the Supreme Court had entertained mandamus suits under $\S 11^{86}$ The Marbury Court itself makes an oblique-and, according to recent scholarship, inaccurate $^{87}$-reference to this earlier mandamus precedent. ${ }^{88}$ As a former attorney general, Lee was well aware of these cases; indeed he cited several of them at oral argument. ${ }^{89}$ In light of these precedents, it is not surprising that Lee would have come first to a (presumably friendly) Supreme Court-especially because it was far from clear what other court might have jurisdiction to issue the writ he sought. ${ }^{\circ 0}$ Yet all but one of the pre-Marbury $\S 13$ cases were arguably exercises of appellate federal question jurisdiction over inferior Article III officers, ${ }^{91}$ and thus perhaps sustainable under the "remedial power" reading of that section. Indeed, Lee himself appeared to argue that Marbury's suit could be seen as an exercise of appellate review, broadly defined, over an "inferior tribunal," even though that tribunal was "ministerial" and not "judicial." And in the one (unreported) pre-Marbury case in which ju-

ss See also text at notes 114-25.

s8 See generally Bloch and Marcus, 1986 Wis L Rev at 304-10 (cited in note 82).

st See id at 310-28.

88 Marbury, 5 US (5 Cranch) at 171-72.

80 Marbury, 5 US (5 Cranch) at 148-49.

-General federal question jurisdiction in lower federal courts had been passed at the end of the Adams administration, but repealed by the incoming Jeffersonians, and did not resurface unti1 1875. Hart \& Wechsler at 960-63 \& nn 9, 28 (cited in note 33). Marbury presumably lacked the requisite diversity of citizenship with Madison, and even if not, the subsequent case of McClung $v$ Silliman, 19 US (6 Wheat) 598 (1821), implied that the circuit courts generally and the state courts would have been closed to him. The Court's holding in Kendall v United States ex rel. Stokes, 37 US (12 Pet) 524, 615-26 (1838), however, did soften the harshness of $\mathrm{McClung}$ by allowing the circuit courts of the District of Columbia to hear mandamus actions like Marbury's.

91 Bloch and Marcus, 1986 Wis L Rev at 323, 327 (cited in note 82).

${ }^{22}$ Marbury, 5 US (1 Cranch) at 146-47; see also id at 147 (arguing that term "appellate jurisdiction" should be taken in "its largest sense"). The Marbury Court explicitly rejects this reading. Id at 175-76. Yet, if the department of state cannot be considered an "inferior tribunal" because, strictly speaking, its officers are not "judges" nor is it a "court" within the meaning of the Constitution, does not this logic suggest serious constitutional difficulties 
risdiction was apparently original, the Supreme Court dismissed the suit without specifying the ground for its decision or explicitly discussing its jurisdiction. ${ }^{93}$

The Marbury Court's reasons for ignoring the "remedial power" reading are easy to imagine. In the middle of a political mine field, and with all eyes upon him, John Marshall managed to empower his branch even as he backed away from a fight with a new and popular President. ${ }^{94}$ By creatively misreading $\S 13$, Marshall could dramatically affirm the doctrine of judicial review in a way that would be unlikely to generate a political backlash. ${ }^{95}$ What's more, amazingly little damage to doctrine would result. The Marbury Court's technical disposition was exactly the same as that required by the "remedial power" reading: dismissal of the case for want of jurisdiction. The only difference is that the Marbury Court's disposition was based on the Constitution, whereas the "remedial power" reading would have led to a purely statutory holding. But even this difference shrinks virtually to a vanishing point if the Marbury Court's view of Article III was correct. If so,

with the entire concept of "legislative" or "Article I" "courts"? See text at notes 43-50.

At another point in his argument, Lee did claim that "Congress is not restrained from conferring original jurisdiction in other cases than those mentioned in the constitution." Id at 148. Yet his argument here seems obviously half-hearted. Unlike his other arguments, he nowhere tried to develop the point; after stating the claim just cited, Lee simply cited a single (off point) lower court case, and dropped the issue. Two weeks later-on either the day before Marbury came down, or the day of the decision itself-Lee explicitly took a position contrary to the one he served up in that case, declaring that "No act of congress can extend the original jurisdiction of the supreme court beyond the bounds limited by the constitution." Stuart v Laird, 5 US (1 Cranch) 299, 305 (1803). See also William E. Nelson, The Eighteenth-Century Background of John Marshall's Constitutional Jurisprudence, 76 Mich L Rev 893, 936-42 (1978).

${ }^{83}$ United States $v$ Hopkins, an unreported case described in Supreme Court docket and minutes, see Maeva Marcus and James R. Perry, eds, 1 The Documentary History of the Supreme Court of the United States, 1789-1800 226-28, 494 (Columbia, 1985). The Hopkins case is also discussed in Bloch and Marcus, 1986 Wis L Rev at 322-23 (cited in note 82 ).

84 Robert G. McCloskey, The American Supreme Court 40 (Chicago, 1960) ("The decision is a masterwork of indirection, a brilliant example of Marshall's capacity to sidestep danger while seeming to court it, to advance in one direction while his opponents are looking in another."); Corwin, 12 Mich L Rev at 543 (cited in note 39) (similar).

${ }^{\text {os }} \mathrm{Had}$ mandamus actually issued, the executive branch may well have disregarded it, and Congress may well have initiated impeachment proceedings against Chief Justice Marshall as well as Justice Chase (who was impeached but acquitted in 1804-05). Stephen B. Presser and Jamil S. Zainaldin, Law and American History 235-59 (West, 1980). By contrast, Marshall's opponents could do little to embarrass his pretensions in Marbury, for the actual holding of the case did not require cooperation from any other branch. The Court's decision to do nothing was brilliantly self-executing, and the immediately apparent result seemed like a victory for Jefferson, thus making it difficult to whip up a popular protest against the Court. 
the worst thing that could be said about Marbury from a technical point of view is that by misinterpreting $\S 13$, the Court needlessly ${ }^{96}$-but correctly-made clear that Congress could not do something that Congress had not (yet) tried to do.

Yet as noted, all this follows only if Marbury was in fact correct in reading Article III as delimiting the maximum amount of Supreme Court original jurisdiction. But is this the best reading of Article III? I shall now try to show that it is.

\section{Second Question: Can Congress Add to the Supreme COURT'S ORIGINAL JURISDICTION?}

Article III sets out the Supreme Court's jurisdiction with characteristic brevity:

In all Cases affecting Ambassadors, other public Ministers and Consuls, and those in which a State shall be Party, the supreme Court shall have original Jurisdiction. In all the other Cases before mentioned, the supreme Court shall have appellate Jurisdiction, both as to Law and Fact, with such Exceptions, and under such Regulations as the Congress shall make. ${ }^{97}$

The Marbury Court treats this language as dispositive:

If it had been intended to leave it in the discretion of the legislature to apportion the judicial power between the supreme and inferior courts according to the will of that body, it would certainly have been useless to have proceeded further than to have defined the judicial power, and the tribunals in which it should be vested. The subsequent part of the section is mere surplusage, is entirely without meaning, if such is to be the construction. If congress remains at liberty to give this court appellate jurisdiction, where the constitution has declared their jurisdiction shall be original; and original jurisdiction where the constitution has declared it shall be appellate; the distribution of jurisdiction, made in the constitution, is form without substance.

Affirmative words are often, in their operation, negative of other objects than those affirmed; and in this case, a negative or exclusive sense must be given to them, or they have no

${ }^{86}$ Of course, this is in keeping with the rest of the opinion, virtually all of which was needless from a narrow "dispute resolution" perspective. See note 39.

${ }^{97}$ US Const, Art III, $\S 2$, cl 2. 
operation at all. ${ }^{98}$

As modern scholars have been quick to point out, the Court overstates the case in claiming that any other reading of Article III leaves its words about original jurisdiction with "no operation at all." ${ }^{\circ}$ Indeed as a matter of logic, there are two main alternatives to the Marbury Court's reading of the Original Jurisdiction Clause as a constitutional maximum. First, the language in Article III could be read to prescribe only a minimum, not a maximum, amount of jurisdiction; second, the language might have been designed to establish neither a minimum nor a maximum but simply a starting point-a default rule-from which Congress may depart by statute in either direction.

Given that each of these alternative readings would leave the words of Article III with some "operation," it seems fair to criticize the Marbury Court for overstating the logical force of its preferred reading. But rhetorical overstatement need not imply an erroneous conclusion. On the issue of judicial review, for example, the Marbury Court has also been criticized for its rhetorical overstatements. ${ }^{100}$ Yet as several modern commentators have demonstrated convincingly, Marbury's conclusions on this count are in the main sound. ${ }^{101}$ As it turns out, the same can be said about its conclusions on the narrow issue of original jurisdiction.

To begin with, we must note that Article III nowhere explicitly countenances additions to Supreme Court original jurisdiction, or declares that the constitutionally specified categories are simply a minimum or a starting point. Taken alone, this is of course hardly dispositive. But as with our earlier experience with the word "power" in $\S 13$, the full significance of the specific wording of the Original Jurisdiction Clause emerges only when this wording is placed in context, and contrasted with the wording of surrounding clauses. $^{.02}$

The Supreme Court's appellate jurisdiction is expressly given "with such Exceptions, and under such Regulations as the Con-

98 Marbury, 5 US (1 Cranch) at 174.

89 Martin Redish, Federal Jurisdiction: Tensions in the Allocation of Judicial Power 11 (Michie, 1980); Currie, 49 U Chi L Rev at 654 (cited in note 13); Van Alstyne, 1969 Duke $\mathrm{L} J$ at 31 \& $\mathrm{n} 44$ (cited in note 12); Bloch and Marcus, $1986 \mathrm{Wis} \mathrm{L}$ Rev at $320-21 \mathrm{n} 73$ (cited in note 82); Corwin, 12 Mich L Rev at 540 (cited in note 39).

${ }^{100}$ See Currie, 49 U Chi L Rev at 655-6l; Van Alstyne, 1969 Duke L J at 16-29; Bickel, Least Dangerous Branch at 1-14 (cited in note 9).

${ }^{101}$ See, for example, Berger, Congress v. The Supreme Court (cited in note 13); Henry

M. Hart, Jr., Professor Crosskey and Judicial Review, 67 Harv L Rev 1456 (1954).

${ }^{102}$ See text at notes 67-80. 
gress shall make." ${ }^{103}$ Here then, we have a plain recognition of congressional power to depart from (at least in one direction) a constitutionally defined starting point. This language tends to support two inferences. First, the appellate jurisdiction may not be added to. The text speaks only of exceptions to-i.e., partial repeal of-Supreme Court appellate jurisdiction. Presumably, had the clause been designed to empower Congress to add to, as well as subtract from, appellate jurisdiction, the language would have read "with such Exceptions, and such Augmentations, as the Congress shall make." But-and this is the second point-why can't the same be said about the Court's original jurisdiction? Why isn't the Appellate Exceptions Clause itself strong evidence that when the framers intended to empower Congress to alter the Constitution's distribution of jurisdiction they used express language to that effect? Put another way, doesn't the very existence of the Exceptions Clause make all the more significant the omission of an "Additions Clause" ("with such additions as the Congress shall make") from the grant of original jurisdiction?

Modern day critics of Marbury seem to intuit the force of this point, but have tried to blunt it with a bold textual countermove that seeks to turn the Exceptions Clause to their advantage. Why, they ask, is not the Exceptions Clause itself a plausible textual warrant for congressional shifting of cases from appellate to original jurisdiction? ${ }^{104}$ Curiously none of these critics has ever attempted to develop this point beyond merely posing the question. Had they attempted to do so, I believe they would have been disappointed.

For starters, the critics' Exceptions Clause gambit seems a somewhat strained reading of the word "exceptions." Strictly speaking, to shift a case from the Court's appellate to its original docket is to do two things simultaneously: to make an "exception"-a subtraction-to appellate jurisdiction and a simultaneous addition to original jurisdiction. The textual basis for the first half is clear enough; it's the second half that is the rub.

To put the point in a slightly different way, we should ask what is the most plausible baseline against which the Exceptions

${ }^{103}$ US Const, Art III, $\S 2$, cl 2.

104 See, for example, Van Alstyne, 1969 Duke L J at 31-32 (cited in note 12); Currie, 49 U Chi L Rev at 654 (cited in note 13); Corwin, 12 Mich L Rev at 540 (cited in note 39); William W. Crosskey, 2 Politics and the Constitution in the History of the United States 1041 (Chicago, 1953); George Lee Haskins and Herbert A. Johnson, 2 History of the Supreme Court of the United States 201 (Macmillan, 1981). 
Clause should be read-original jurisdiction in tbe Supreme Court, or final jurisdiction in some other court? The critics' gambit rests on an implicit premise that the Supreme Court, and only the Supreme Court, should have the final say (at least within the judiciary system) on every one of the cases and controversies in the Article III jurisdictional menu. But whence this premise? Professor Van Alstyne claims it derives from the other words in Article III: "Article III itself provides that 'the judicial Power of the United States shall be vested in one supreme Court." "10s But Professor Van Alstyne has omitted the rest of the relevant passage from Article III, which reads in full:

The judicial Power of the United States, shall be vested in one supreme Court, and in such inferior Courts, as the Congress may from time to time ordain and establish. ${ }^{106}$

No violence is done to the Article III mandate that the judicial power shall extend to all cases in certain categories, and shall be vested in the federal judiciary if a case is "excepted" from the Supreme Court's appellate jurisdiction in favor of lower federal courts, and not (as Van Alstyne would have it) in favor of Supreme Court original jurisdiction. ${ }^{107}$

Although my (and the Marshall Court's) ${ }^{108}$ reading of the Exceptions Clause does allow Congress to circumvent Supreme Court judicial review, it does not allow any circumvention of Article III judicial review, for any federal question case "excepted" from the Supreme Court's appellate jurisdiction must be finally decided in some other Article III tribunal, ${ }^{109}$ thus preserving the co-ordinacy of that branch. ${ }^{110}$ Since all Article III judges are safeguarded by

\section{Alstyne).}

10 Van Alstyne, 1969 Duke L J at 33 (cited in note 12) (emphasis added by Van

106 US Const, Art III, $\$ 1$ (emphasis added); see generally Amar, 65 BU L Rev at 231-38 \& $\mathbf{n} 88$ (cited in note 12 ).

${ }^{107}$ Nor does this solution deny the Supreme Court's unique constitutional position. The Supreme Court remains supreme in that it derives its existence and jurisdiction directly from the Constitution, and in that it is the only court from which no appeal can constitutionally lie. See Amar, 65 BU L Rev at 221 n 60 (cited in note 12).

${ }_{108}$ In addition to Marbury, see also United States $v$ More, 7 US (3 Cranch) 159 (1805) (discussed in note 51); Martin $v$ Hunter's Lessee, 14 US (1 Wheat) 304 (1816) (discussed generally in Amar, $65 \mathrm{BU} \mathrm{L}$ Rev at 210-20 (cited in note 12)).

109 See generally Amar, 65 BU L Rev at 229-59 (cited in note 12).

$110 \mathrm{It}$ is a great mistake to conflate the Supreme Court with the third branch of government established by the Constitution, i.e., the Judicial Department. See US Const, Art I, § 8, cl 18. See Amar, 65 BU L Rev at 231-38 \& n 115 (cited in note 12). Though the power to assign final jurisdiction to a federal court other than the Supreme Court could be abused, so too can other congressional powers over the courts, for example, the power to "pack" the 
the same structural protections-Presidential appointment, Senate confirmation, life tenure, undiminishable salary, removability by impeachment and so on-all are equally vested with the judicial power of the United States; ${ }^{111}$ all are equally capable of resolving finally the cases and controversies spelled out in the Article III menu. Indeed, all Article III officers-of both Supreme and inferior courts-are given the same constitutional title: Article III "judge." The Constitution nowhere distinguishes between Supreme Court "Justices" and lower court "judges"112 - this modern linguistic convention is an extra-constitutional excrescence traceable to our old friend, the Judiciary Act of $1789 .{ }^{113}$

Thus, far from strengthening the plausibility of the "exceptions" gambit, other words from Article III-vesting "judicial power" in "judges" guaranteed identical status attributes-tend to support the more natural reading of the Exceptions Clause: exceptions to Supreme Court appellate jurisdiction in federal question cases like Marbury are made not in favor of Supreme Court original jurisdiction, but in favor of other federal courts.

The history of the Exceptions Clause further undermines the modern critics' view. At the Philadelphia Convention, early draft language of the Exceptions Clause would have allowed Congress to shift cases from the Court's appellate to its original docket, but this language never came out of committee. ${ }^{114}$ Moreover, on one occasion the Convention explicitly rejected two proposed amendments to Article III-one to the Exceptions Clause itself-that

Court. Indeed, the court packing and jurisdiction stripping powers are quite similar: both give Congress authority simply to choose which (presumptively equal) Article III officers shall have the last judicial word on federal questions. Neither power authorizes Congress to give the last word to judges lacking Article III protections. See id at 258-59.

11 See generally Amar, 65 BU L Rev at 220-22, 231-38 (cited in note 12). See also Letter from Associate Justice Samuel Chase to Chief Justice John Marshall, April 24, 1802, in Haskins and Johnson, 2 History of the Supreme Court at 172-76 (cited in note 104): "Judges of the inferior courts were intended, by the Constitution to be as independent as the judges [sic] of the Supreme Court. ... [Their independence] is as essentially necessary to guard the Constitution ... a the independence of the judges [sic] of the Supreme Court."

112 US Const, Art III, $\$ 1$ ("The Judges, both of the supreme and inferior Courts. . ."). Of course, the Constitution does single out the Chief Justice, who is to preside over impeachment trials of the President. US Const, Art I, § 3, cl 6.

11 Judiciary Act of 1789 , ch $20, \S 1,1$ Stat 73 ("[T] States shall consist of a chief justice and five associate justices ..."); id § 3 (each district shall have one judge who "shall be called a District Judge").

114 Max Farrand, ed, 2 The Records of the Federal Convention of 1787147 (Yale, 1911) ("Farrand") "But this supreme jurisdiction shall be appellate only, except in [Cases of Impeachmt. \& (in)] those instances, in which the legislature shall make it original."[sic] (Draft from the Committee of Detail)). 
would have permitted augmenting the Supreme Court's original jurisdiction. ${ }^{115}$ During the ratification era, I know of not a single person, Federalist or Anti-Federalist, who claimed that Congress-under its "exceptions" power or any other power-would have authority to add to the Supreme Court's original jurisdiction. And as we have seen, once $\S 13$ is properly read, we cannot tax any of the early Congresses with such a view. ${ }^{116}$ Although it's hard to prove a negative, I should note that none of the modern day critics of Marbury has identified a single eighteenth century source supportive of their proffered readings of the Exceptions and Original Jurisdiction Clauses.

On the other side of the debate, there exists abundant historical evidence to support the Marbury Court. Federalists assured their audience during the ratification period that the Supreme Court's original jurisdiction would extend "only" to the categories enumerated in Article III; ${ }^{117}$ that the Court's original jurisdiction "would be confined to two classes of cases, and those of a nature rarely to occur"; ;18 that in "all other cases of federal cognizance the original jurisdiction would appertain to the inferior tribunals; and the Supreme Court would have nothing more than an appellate jurisdiction"; 119 that "a very small portion of original jurisdiction has been reserved to the Supreme Court and the rest consigned to the subordinate tribunals"; ${ }^{20}$ that the Constitution "excludes [Supreme Court] original jurisdiction in all other cases"; 121 that "the legislature cannot extend its original jurisdiction, which is limited to these cases only"; ${ }^{122}$ and that the language

115 See 2 Farrand at 425,431 . The Convention rejected a proposal to alter the Exceptions Clause to read: "In all the other cases before mentioned the judicial power shall be exercised in such a manner as the Legislature shall direct."; id at 425. The Convention also rejected the proposed alteration: "But in cases to which the United States shall be a party, the jurisdiction shall be original or appellate as the legislature may direct." See also id at 430-32. For a discussion of the significance of the interconnected changes made by the Convention on this day, see Amar, 65 BU L Rev at 241-42 n 120 (cited in note 12); Clinton, 132 $\mathrm{U} P \mathrm{~Pa}$ Rev at 787-94 (cited in note 52); Lawrence Gene Sager, The Supreme Court 1980 Term - Foreword: Constitutional Limitations on Congress' Authority to Regulate the Jurisdiction of the Federal Courts, 95 Harv L Rev 17, 49-50 n 95 (1981); Hart \& Wechsler 1112 n 46 (cited in note 33).

${ }_{116}$ See text at notes 82-85.

112 Federalist 81 (Hamilton) in Clinton Rossiter, ed, The Federalist Papers 481, 487 (Mentor, 1961).

118 Id at 488.

110 Id.

120 Id at 491.

1213 Elliot's Debates at 518 (cited in note 82) (remarks of Edmund Pendleton at the Virginia ratifying convention).

122 Id. 
of the Exceptions Clause empowered Congress only to make subtractions from the Court's appellate docket in favor of other courts. ${ }^{123}$ After the Constitution's adoption, both Chief Justice Jay $^{124}$ and Justice Chase ${ }^{125}$ premised their challenges to the constitutionality of circuit riding on the (to them) seemingly self-evident proposition that the original jurisdiction of the Supreme Court could not be expanded. Finally, we should not forget the unanimity of the Marbury Court itself on this point, and the absence of contemporary challenges to the opinion on this question.

What accounts for this striking consensus? Surely not the brute force of the words themselves, as Marshall implied in Marbury. On this count, modern day criticism of the sterility of the opinion's analysis of Article III is well taken. But has not my argument thus far suffered from a similar sterility, based in part on rather formal interpretive moves like expressio unius est exclusio alterius? Is there not some larger, purposive logic at work in the allocation of Supreme Court jurisdiction that provides an account not simply of what Article III says, but why? I believe there is such a logic, and it can be summed up in one word: geography. Let me explain.

Geography preoccupied the founding generation. The Federalists keenly understood the enormity-in every sense of that word, including geographic-of the task to which they had set their minds: the creation of a republican government stretching across an entire continent. Anti-Federalist skeptics insisted it couldn't be done, and invoked both the models of classical republics (Greek and Italian city-states small enough for all citizens to come together and meet face to face) and the best enlightenment political

${ }^{123}$ Many quotations to this effect may be found in sources cited in Amar, 65 BU L Rev at $257 \mathrm{n} 166$ (cited in note 12); Clinton, $132 \mathrm{U} \mathrm{Pa} \mathrm{L} \mathrm{Rev} \mathrm{at} \mathrm{797-837} \mathrm{(cited} \mathrm{in} \mathrm{note} \mathrm{52).}$

124 See Letter from Chief Justice Jay to President Washington, April 3, 1790, in 3 Joseph Story, Commentaries on the Constitution of the United States $\$ 1573$ at $440 \mathrm{nl}$ (1833) (DaCapo, 1970) (circuit courts unconstitutionally vested with "original jurisdiction in the cases, from which the Supreme Court is excluded"). This letter may never have been sent. See Russell Wheeler, Extrajudicial Activities of the Early Supreme Court, 1973 S Ct Rev $123,148$.

${ }^{125}$ See Letter from Samuel Chase to John Marshall, April 24, 1802, reprinted in Haskins and Johnson, 2 History of the Supreme Court at 172-76 n 182 (cited in note 104) (emphasis in original):

I much doubt, whether the Supreme Court can be vested, by Law, with original jurisdiction, in any other cases, than the very few enumerated in the Constitution.... The Constitution intended that the Judges [sic] of the Supreme Court should not have original jurisdiction, but only in the few cases enumerated. The inference is just that, as the Constitution only gave the Supreme Court original jurisdiction in a few specified cases, it intended to exclude them from original Jurisdiction in all other Cases; 
science available (especially Montesquieu's claims that republics could be of only limited size, in part because divergent climates would create divergent cultures). ${ }^{126}$ Even so ardent a nationalist as Alexander Hamilton wondered aloud at the Philadelphia Convention whether such a diverse empire could be governed consistently with proper republican principles: "The extent of the Country to be governed, discouraged him. ... This view of the subject almost led him to despair that a Republican Govt. could be established over so great an extent." ${ }^{\text {127 }}$ Indeed, the entire first section of the Federalist Papers, spanning numbers 1 through 14, can be seen as variations on the theme of whether a "republic may be extended over a large region."128

Geography ramified in every direction, influencing virtually

${ }^{126}$ See, for example, Cecelia M. Kenyon, The Political Thought of the Antifederalists, in Cecelia M. Kenyon, ed, The Antifederalists xxxix-xlii (Bobbs-Merrill, 1966); Letters of Agrippa IV, in id at 133; Letter of Cato to the Citizens of New York, in Herbert J. Storing, ed, 2 The Complete Anti-Federalist 109, 110-112 (Chicago, 1981); Essays of Brutus, in 2 id at 363, 368-71. For responses see Federalist 14 (Madison), in Federalist Papers at 99, 100 (cited in note 117) (noting the turbulent Greek and Italian experience in democracy); Federalist 9 (Hamilton), in id at 71, 73-74 (reinterpreting Montesquieu's argument).

1271 Farrand at 287-88 (cited in note 114).

${ }^{128}$ Federalist 14 (Madison), in Federalist Papers at 99, 100 (cited in note 117). In Federalist 2, Jay notes the many ways in which (white male) Americans shared a basic homogeneity that constituted them as one people, ethnically, culturally, linguistically, and historically:

Providence has been pleased to give us this one connected country to one united people-a people descended from the same ancestors, speaking the same language, professing the same religion, attached to the same principles of government, very similar in their manners and customs, and who, by their joint counsels, arms, and efforts, fighting side by side throughout a long and bloody war, have nobly established their general liberty and independence.

Federalist 2, in id at 38. But this oft-quoted passage is itself framed by less famous language that speaks of the geographic unity of America:

[I]ndependent America was not composed of detached and distinct territories, but [rather consists of] one connected, fertile, spreading country .... A succession of navigable waters forms a kind of chain round its borders, as if to bind it together; while the most noble rivers in the world, running at convenient distances, present [its inhabitants] with highways for the easy communication of friendly aids and the mutual transId. portation and exchange of their various commodities.

Over the next several papers, Jay and Hamilton develop a brilliant geopolitical and military argument for union, sketching the general inability of small republics to defend themselves against external threats while maintaining internal democracy; noting the tremendous strategic advantage offered by a three-thousand mile wide ocean between Europe and America; analyzing the strategic and political differences between land borders and sea borders; and strongly anticipating the Monroe Doctrine. Finally, Madison takes the stage and stresses the purely domestic reasons, rooted in internal principles of republicanism, for preferring a large state. See Federalist 10, 14. The last sentence of No. 14 marks the end of the first section of the Federalist Papers, rhetorically signalling closure by its echo of the language of the first sentence of No. 1. 
every major issue considered by the Philadelphia Convention: Should Congress be given a veto over state laws? ${ }^{129}$ How should the President be chosen? ${ }^{130}$ How long should members of the House of Representatives sit? ${ }^{131}$ How "high toned" should the national government be? ${ }^{132}$ Who should pay congressional salaries? ${ }^{133}$ It is thus hardly surprising that geography also importantly influenced the allocation of Supreme Court jurisdiction.

It is geography that answers the 'following question: Why, if "judges of both supreme and inferior [federal] courts" are basically equal (as I have argued ${ }^{\mathbf{1 3 4}}$ ), is Congress permitted to provide for lower federal court original jurisdiction, but not Supreme Court original jurisdiction, in categories other than ambassador and state party cases? As George Mason observed in discussing the proposed council of revision during the first week of the Philadelphia Convention:

[T] he federal inferior courts of justice must, I presume, be fixed in the several respective States, and consequently most of them [will be] at a great distance from the seat of the federal government [where] only the judges [sic] of the Supreme Federal Court [will be] fixed. ${ }^{135}$

The following day, during the Convention's first discussion of the structure of the federal judiciary, James Madison echoed his Virginia colleague: "To order a ... trial at the supreme bar would oblige the parties to bring up their witnesses, tho' ever so distant

129 In an argument no doubt meant to recall the unhappy experience of delays occasioned by Privy Council review of colonial policy, Gunning Bedford asked whether "the laws of the States [are] to be suspended in the most urgent cases until they can be sent seven or eight hundred miles." 1 Farrand at 167 (cited in note 114).

${ }^{130}$ In response to Elbridge Gerry's proposal to allow state executives to elect the President, Edmund Randolph pointed to "the expense and difficulty of bringing the executives to one place to exercise their powers." Id at 181.

131 James Madison argued early on for a three year term, noting that "[o]ne year will be almost consumed in preparing for and traveling to \& from the seat of national business." Id at 214. See also id at 361 (similar); Federalist 53 (Madison) in Federalist Papers at 334-35 (cited in note 117).

${ }^{132}$ Hamilton's famous June 18 speech urged the creation of a set of powerful and relatively insulated national offices to lure the nation's best and brightest into national service: "Wbat can be the inducements for gentlemen to come 600 miles to a national legislature? The expense would at least amount to $£ 100,000 . " 1$ Farrand at 298 (cited in note 114).

133 "Payment by the States would be unequal as the distant States would have to pay for the same term of attendance and more days in travelling to \& from the seat of the Govt." Id at 373 (remarks of Alexander Hamilton).

${ }^{234}$ See text at notes 111-13.

sss 1 Farrand at 111 (cited in note 114). 
from the seat of the Court."136

During the Virginia ratifying convention, it was none other than John Marshall who drove home the geographic point. After briefly alluding to the structural parity of all Article III judges in terms of "independence in office" and "manner of appointment," 137 Marshall underscored the geographic difference between Supreme Court and lower federal court officers:

I did not conceive that the power of increasing the number of courts could be objected to by any gentleman, as it would remove the inconvenience of being dragged to the centre of the United States. ${ }^{138}$

This geographic concern also lies at the heart of the sentence of Article III that immediately follows the language allocating Supreme Court jurisdiction: "The trial of all Crimes, except in Cases of Impeachment, shall be by Jury; and such Trial shall be held in the State where the said Crimes shall have been committed."139

But if geography was such a dominant concern, why did the framers allow the Supreme Court to exercise even appellate jurisdiction in the great run of cases? First, because appellate jurisdiction would typically not require that litigants, witnesses, and physical evidence be "dragged to the centre"; only the record of the case would need to be sent to the nation's capital. Thus the dominant concern was the venue of trial, as is clear from the Article III language concerning criminal trials. As this language also reveals, the venue issue was also connected up with a preference for local

${ }^{136}$ Id at 124. See also the revealing language of Hamilton's proposed Constitution, which gave Congress "power to institute [inferior] Courts in each State." Id at 292 (emphasis added).

${ }^{197} 3$ Elliot's Debates at 552 (cited in note 82).

${ }^{138}$ Id at 552-53. Of course even the geographic disparity between inferior and Supreme Court judges was perhaps contingent rather than constitutionally ordained. Unlike Hamilton's proposed language, see note 136, the Constitution does not specify where the inferior courts must be located. Thus Congress is not explicitly barred from creating lower federal courts located only in the nation's capital. Yet none of the founders seems to have contemplated such an outlandish possibility: all assumed that if Congress created lower courts, most would be located in the hinterlands. And if Congress did not create any lower courts, as contemplated by the Madisonian Compromise, state courts would exercise original jurisdiction. See Amar, 65 BU L Rev at 212-14, 255-57 n 165 (cited in note 12). In any event, it would likely be more difficult politically for Congress to create new lower courts only in the nation's capital than to simply add to the existing original jurisdiction of an existing-indeed, a constitutionally mandated-Supreme Court. See id at $221 \mathrm{n}$ 60. What's more, the allocative provisions of Article III would themselves add to the political cost: creation of only national capital courts could plausibly be argued by political opponents to be a perversion of the "venue" spirit of Article III. See id at 267 \& n 206.

${ }^{239}$ US Const, Art III, § 2, cl 3. See also id, Amend VI. 
juries, who would be more familiar witb the parties and witnesses, and thus in a better position to assess their credibility and character. ${ }^{140}$ Subsequent adoption of the Fifth, Sixth, and Seventh Amendments, limiting appellate relitigation of facts found by a local jury, further illustrates the notion that appellate review was generally not seen as authorizing a "new trial"141 by the appellate judges. ${ }^{142}$

Second, if mere appellate jurisdiction ever proved too geographically onerous in practice, the Federalists emphasized that Congress could make exceptions to the Supreme Court's appellate jurisdiction and instead allow inferior Article III judges within each state to be the last word, even on federal questions. As Madison explained in Philadelphia, "unless inferior tribunals were dispersed throughout the Republic with final jurisdiction, in many cases, appeals" to the "ever so distant" Supreme Court "would be multiplied to a most oppressive degree." 143 This geographical theme is also a strong motif running through Hamilton's Federalist 81 and 82 . In 81, for example, he writes:

The power of constituting inferior courts is evidently calculated to obviate the necessity of having recourse to the Supreme Court in every case of federal cognizance. It is intended to enable the national government to institute ... in each State ... a tribunal competent to the determination of matters of national jurisdiction within its [i.e., the state's geo-

140 George Mason's reference to "a respectable witness" in the following passage was typical: "Perhaps I have a respectable witness who saw me pay the money; but I must carry him one thousand miles to prove it, or be compelled to pay it again." 3 Elliot's Debates at 526 (cited in note 82).

141 Farrand at 124 (cited in note 114) (remarks of James Madison).

142 Article III, of course, does extend appellate jurisdiction over both law and fact. Indeed, in situations where "constitutional" facts are at issue, the principles underlying Marbury may require judicial power to review such facts de novo. Yet Article III jurisdiction over facts is limited by, inter alia, the double jeopardy provisions of the Fifth Amendment and the Sixth and Seventh Amendment jury guarantees. Apart from these limits, even where Congress has general power to authorize de novo Supreme Court appellate review of ordinary fact as well as law on appeal, the mere requirement that Congress first allow the case to be tried outside the Supreme Court makes congressional authorization of a "new trial" in that Court more politically costly.

1431 Farrand at 124 (cited in note 114). See also Letters of a Federal Farmer, in Kenyon, ed, The Antifederalists at 210 (cited in note 126) ("the one supreme court at most could only set in the centre of the union and move once a year into the centre of the eastern and southern extremes of it-and in this case, each citizen, on an average, would travel 150 to 200 miles to find this court-that, however, inferior courts might be properly placed in the different counties, and districts of the union, the appellate jurisdiction would be intolerable and expensive"); Brutus XIV, in Storing, ed., The Complete Anti-Federalist at 434-35 (cited in note 126) (similar). 
graphical] limits. ${ }^{144}$

In the very next Federalist Paper, we find the following passage:

I perceive at present no impediment to the establishment of an appeal from the State courts to the subordinate national tribunals; and many advantages attending the power of doing it may be imagined. ... [A]ppeals, in most cases in which they may be deemed proper, instead of being carried to the Supreme Court may be made to lie from the State courts to district courts of the Union. ${ }^{145}$

Although geography is less obvious on the face of this last passage, context makes clear Hamilton's animating concern with location. ${ }^{146}$ And when even this passage alone is examined more closely, geographical allusion can be discerned: Appeals must be "carried" to the Supreme Court-recall Marshall's evocative language of being "dragged to the centre"147 — whereas they will simply "lie," under Newton's law of inertia, in the lower federal courts located alongside $^{148}$ state tribunals.

Veiled geographic allusions also appear in Chief Justice Jay's 1790 letter to President Washington. After a rather formalistic claim that the Constitution "exclude[s]" the Supreme Court from exercising original jurisdiction beyond the bounds laid down in Ar-

144 Federalist 81 (Hamilton), in Federalist Papers at 485 (cited in note 117).

${ }^{145}$ Federalist 82 (Hamilton), in Federalist Papers at 495 (cited in note 117). For other qualified endorsements of a jurisdictional regime in which lower federal courts sit in appellate review over state tribunals, see Amar, 65 BU L Rev at 269-70 (cited in note 12); Henry M. Hart, Jr., The Relations Between State and Federal Law, 54 Colum L Rev 489, 540 (1954); Paul M. Bator, The State Courts and Federal Constitutional Litigation, 22 Wm \& Mary L Rev 605, 635-36 (1981).

${ }^{146}$ For an earlier Hamiltonian discussion of the connection between geography and adjudication, see Federalist 65 in Federalist Papers at 400 (cited in note 117) (Impeachment court "must either consist of permanent officers stationary at the seat of government, ... or certain officers of the state governments, to be called upon whenever an impeachment was actually depending. ... The second [mode] will be espoused with caution by those, who will seriously consider the difficulty of collecting men dispersed over the whole Union.").

${ }^{147}$ See text at note 138. See also Letter of John DeWitt in Kenyon, ed, The Antifederalists at 101 (cited in note 126) (discussing "right to carry causes to the Supreme Court of the United States whether for delay only or vexation; however distant from the place of your abode"); Speech of George Mason at Virginia ratifying convention in id at 269-70 (using verb "to carry" three times in conjunction with three separate reminders that Supreme Court may be located "one thousand miles" from trial court); Speech of William Lancaster in North Carolina ratifying convention in id at 417-18 (similar geographic use of "carry").

${ }^{148}$ See, for example, the spatial metaphor of the Court in Klaxon Co. $v$ Stentor Electric Co., 313 US 487, 496 (1941) (speaking of "coordinate state and federal courts sitting side by side"). 
ticle III, Jay made a pointed allusion to the "defects in the [Judiciary Act] relative to expediency"148 — a direct reference to a specific passage in Attorney General Randolph's First Report to Congress, in which Randolph criticized the "expediency" of circuit riding, with its attendant "fatigue" and "loss of leisure." cuit riding placed the geographic onus on judges rather than on litigants, but the connection between geography and the allocation of Supreme Court jurisdiction is a constant. ${ }^{151}$ Indeed, in a later section of the First Report, Randolph explicitly declared that it was "doubtful" that the Supreme Court's original jurisdiction could be expanded by Congress. ${ }^{152}$

Perhaps the most elegant integration of the formal (expressio unius) and functional (geographic) arguments against expansion of Supreme Court original jurisdiction came from Associate Justice Samuel Chase's April 1802 letter to Chief Justice Marshall:

I much doubt, whether the Supreme Court can be vested, by Law, with original jurisdiction, in any other Cases than the very few enumerated in the Constitution. In all other Cases, to which the Judicial power of the United States extends, the Supreme Court is vested with an appellate Jurisdiction; and if it can have original Jurisdiction, in other cases, the citizen would be deprived of the benefit of a hearing in the inferior Tribunals; and obliged to resort, in the commencement of his Suit, to the Supreme Court. ${ }^{153}$

\footnotetext{
140 See Letter from Chief Justice Jay to President Washington, April 3, 1790, in Story, 3 Commentaries $\S 1573$ at $440-41$ (cited in note 124).

${ }^{150}$ First Report of the Attorney General of the United States, 7-8 (Child \& Swaine, 1791). For a colorful account of the physical onus of circuit travel, see Holt, "The Federal Courts Have Enemies in All who Fear Their Influence on State Objects": The Failure to Abolish Supreme Court Circuit Riding in the Judiciary Acts of 1792 and 1793, 36 Buff L Rev 301 (1987).

${ }^{152}$ Circuit riding raised important and difficult constitutional issues. On the one hand, it could be argued that Congress had impermissibly extended the de facto original jurisdiction of the Supreme Court. Yet on the other hand, it could be argued that circuit justices hearing cases were not sitting qua Supreme Court, but qua inferior (circuit court) officers. This formal distinction could be buttressed by arguing that the geographic reason behind the restriction on Supreme Court original jurisdiction no longer obtained when the travel burden was shifted from litigant to judge. Yet conceptualizing Supreme Court Justices as dual office holders raises serious constitutional problems of its own, not the least of which implicates the Appointments Clause. See Currie, $49 \mathrm{U}$ Chi L Rev at 663-64 (cited in note 13).

162 First Report at 31 (cited in note 150).

${ }^{153}$ Letter from Samuel Chase to John Marshall, April 24, 1802, reprinted in Haskins and Johnson, 2 History of the Supreme Court at 172-73 (cited in note 104) (emphasis in original).
} 
After repeatedly underscoring the words of Article III, Chase illustrated-in a way that Chief Justice Marshall's opinion in Marbury did not-how these words were designed for the "benefit" of a "citizen" who sought a local trial ("hearing"). To expand the Supreme Court's original jurisdiction would be to impose a geographic onus on the citizen, "oblig[ing]" him to "resort"-from the French sortir, to go out, to issue forth ${ }^{164}$ - to the distant Supreme Court.

The "venue" reading of Article III's allocation of jurisdiction also provides a nice account of why the Supreme Court is given original jurisdiction over a "very few enumerated" categories of ambassador and state-party cases. ${ }^{155}$ Cases affecting "Ambassadors, public Ministers, and Consuls" were most likely to arise in the nation's capital and diplomatic seat, where such foreign dignitaries had been received by the President. ${ }^{156}$ Thus, geographic convenience (from the foreign dignitaries' point of view) ${ }^{\mathbf{1 5 7}}$ would generally favor trial in a court "fixed"158 at the seat of government. The peculiar international delicacy of such cases also strongly argued for allowing original jurisdiction in the capital, to enable immediate communication with executive officials about any fastbreaking international developments.

For lawsuits in which "a State shall be Party," geographic inconvenience was also likely to be minimal; each state would have permanent representatives in the national seat-members of the House and Senate-who could be relied on to attend to the state's litigation interests. In fact, geographic considerations tended affirmatively to support Supreme Court original jurisdiction over state party cases. Consider, for example, as a quintessential state party dispute, a suit between two states, Massachusetts and Georgia. To refuse to allow the Supreme Court to exercise original jurisdiction would mean that trial would most likely be held in either a

154 13 Oxford English Dictionary 729 (Clarendon, 2d ed 1989). Chase was probably much more sensitive to the origins of the word than a modern reader since, as any eighteenth century lawyer, he was learned in Latin and law French.

${ }^{185}$ Compare A Manifesto of a Number of Gentlemen from Albany County in Kenyon, ed, The Antifederalists at 362-64 (cited in note 126) (Anti-Federalist tract objecting to any Supreme Court original jurisdiction and noting that inferior courts would be located in the states).

${ }^{168}$ See US Const, Art II, $\S 3$; Amar, 65 BU L Rev at 253-54 (cited in note 12).

${ }^{167}$ See Ames $v$ Kansas ex rel. Johnston, 111 US 449, 464 (1883) (noting that this grant of Supreme Court original jurisdiction was intended as benefit for foreign dignitaries); Amar, 65 BU L Rev at $261 \mathrm{n} 183$ (cited in note 12) (similar).

${ }^{158} 1$ Farrand at 111 (cited in note 114) (remarks of George Mason); for full quote see text at note 135 . 
state or lower federal court in one of the two states. Suit in state court must have seemed an especially unhappy possibility, in tension with general principles underlying the maxim that "[n]o man ought certainly to be a judge in his own cause."159 Indeed, it was probably far from clear whether a state court could properly exercise jurisdiction unless the defendant state consented. Yet real or perceived partiality made such consent unlikely. A similar problem might bedevil even a lower federal court that sought to adjudicate the dispute. One of the two states would enjoy an unseemly "home field" advantage. Notwithstanding the general structural parity of Article III judges, lower court officials were likely to have provincial ties. The presiding judge at trial was likely to have come from the forum state, or at least be a current resident. Jurors, too, were likely to be influenced by their local ties. And even if no real or perceived bias existed on the bench and in the jury box, one of the states would nevertheless have to "resort" to the territory of its opponent, and bear an unfair share of the time, expense, and fatigue of eighteenth century travel. Symbolically, at least, the Supreme Court would be a purely neutral forum, metaphorically (if not geographically) equi-distant between the two contending states.

In the end, the geographic story seems to be powerfully explanatory. It can provide a plausible account of why various categories of cases were either included in, or excluded from, Supreme Court original jurisdiction. What's more, this account coheres with surrounding language of Article III, emphasizing the general structural parity of all federal judges, the permissibility of congressional exceptions to Supreme Court appellate jurisdiction, and the venue rights of criminal defendants. And it illustrates interesting connections between the issues in Marbury on the one hand, and those implicated by the Fifth, Sixth, and Seventh Amendments, and by the circuit-riding controversy, on the other.

As with our earlier discussion of the reasons behind Charles Lee's and the Marbury Court's apparent misreading of $\S 13$, it remains to ask why, if the geographic account is such a plausible one, modern day scholars seem to have overlooked it. One answer is perhaps that moderns tend to forget how different America was 200 years ago-how much more arduous it was to travel from New York to Washington, D.C. in a world without I-95 and the Eastern Shuttle. ${ }^{160}$ Ironically, the framers themselves had a better sense of

${ }^{168}$ Federalist 80 (Hamilton), in Federalist Papers at 478 (cited in note 117).

${ }^{180}$ It might perhaps be argued that these changed circumstances have wholly mooted 
history, for they anticipated the possibility that improvements in communication and transportation would lead to increases in commerce of both persons and goods among the states, and make the United States a "smaller" nation. ${ }^{161}$ In such a nation, state court parochialism would be less of a problem, and the corresponding need for federal jurisdiction to deal with this parochialism would be reduced. The framers were so farsighted as to structure Article III to accommodate such changes by allowing Congress to dispense with federal diversity jurisdiction. ${ }^{162}$ Indeed, I shall now argue, they even empowered Congress to remove state-diversity cases from the federal courts altogether, and thus reduce the Supreme Court's original jurisdiction.

\section{Third Question: Can Congress Take Away from the Supreme Court's Original JuRisdiction?}

In an earlier essay, ${ }^{163}$ I argued that the Article III jurisdictional menu extending the judicial power to nine enumerated categories of "Cases" and "Controversies" was divided into two fundamentally different tiers. In the first tier, consisting of ambassador, "arising under" and admiralty cases, the judicial power of the United States must extend to "all Cases"-those words are used three separate times to define the three categories. In the second tier, comprising six diversity-type controversies defined by party status, the word "all" nowhere appears.

This textual difference, I argued, was reinforced by major structural differences between the first and second tiers, as well as

the geographic logic of the Original Jurisdiction Clause. Yet even today, geography continues to loom large in forum allocation policy, through doctrines of venue, personal jurisdiction, and forum non conveniens. What's more, a changed circumstances argument for disregarding the wording of the Original Jurisdiction Clause could probably not be limited to that clause alone; precisely because geography was such a pervasive concern in framing the Constitution, virtually every part of the document would be vulnerable to an analogous argument from changed circumstances. In addition, the Federalists themselves expected transportation to improve in the future, and indeed, premised their system in part on those expectations. See text at notes 161-62. Compare Amar, 96 Yale L J at $1487 \mathrm{n} 246$ (cited in note 27).

In any event, the changed circumstances argument is tangential to my main argument in this section, which is to show that in 1803 , the Marbury Court was correct in reading Article III as delimiting the maximum amount of Supreme Court original jurisdiction.

${ }_{101}$ Martin Diamond, The Federalist's View of Federalism, in Essays in Federalism 21, 49-50 (Institute for Studies in Federalism, 1961); Federalist 53 (Madison), in Federalist Papers at 334 (cited in note 117); Federalist 60 (Hamilton), in id at 367.

${ }^{162}$ See Amar, 65 BU L Rev at 245-46 (cited in note 12).

${ }^{163}$ Id at 205. 
by historical evidence and precedent. ${ }^{164}$ On the basis of all this, I concluded that Congress had virtually plenary power to strip the entire federal judiciary of jurisdiction over "permissive" second tier lawsuits, but that Congress had no such power over the first, "mandatory" tier: all cases in the mandatory tier had to be capable of being heard and finally resolved-at least on appeal-by some Article III court, supreme or inferior.

My main focus in that essay was on the Exceptions Clause and the Supreme Court's appellate jurisdiction. ${ }^{165}$ Under the two-tiered thesis, Congress has virtually plenary power to strip away appellate jurisdiction in, say, diversity cases, thus leaving the state courts as final arbiters of these controversies. But congressional power over federal question and admiralty cases is far more limited. Congress may except such cases from the Supreme Court's appellate docket only if Congress simultaneously authorizes some other Article III court(s) to hear, at least on appeal, all excepted cases.

But the two-tiered thesis also has interesting implications for the Supreme Court's original jurisdiction, which I only noted in passing. ${ }^{166}$ For not all permissive tier controversies are covered by the Exceptions Clause. Indeed, half of the permissive tier categories fall within the Supreme Court's original jurisdiction over lawsuits "in which a State shall be Party," referring back to ${ }^{167}$ "Controversies between two or more States; between a State and Citizens of another State; . . . and between a State . . . and foreign States, Citizens or Subjects." Given that such cases fall in the permissive tier, I argued that Congress could virtually eliminate all federal jurisdiction, including Supreme Court original jurisdiction, over them. ${ }^{168}$

But how is this consistent with the language of the Original Jurisdiction Clause, which of course, has no express Exceptions Clause? If, as I have argued above, ${ }^{169}$ the absence of an explicit congressional empowerment to add to the Supreme Court's original jurisdiction takes on added significance in light of the adjoining language explicitly empowering congressional exceptions to appellate jurisdiction, why is not the apparent absence of an explicit

164 Id at 242-54.

105 Id at 254-59.

${ }^{208}$ Id at $254 \mathrm{n} 160$.

${ }^{187}$ For a more careful discussion of the precise connection between the state party language of the Original Jurisdiction Clause and the language of the jurisdictional menu, see section $\mathrm{V}$.

18365 BU L Rev at $254 \mathrm{n} 160$.

${ }^{169}$ See text at note 103. 
congressional empowerment to reduce the Court's original jurisdiction equally significant? I believe that careful re-examination of the words of the Original Jurisdiction Clause, and of other words in the Constitution, will reveal an explicit (if often overlooked) basis for congressional authority over permissive tier original jurisdiction in the Supreme Court. Moreover, my reading of the Original Jurisdiction Clause is consistent with early Supreme Court interpretations of Article III.

\section{A. Constitutional Text}

Once again, let us begin by focusing on the words of the Original Jurisdiction Clause: "In all Cases affecting Ambassadors, other public Ministers and Consuls, and those in which a State shall be Party, the supreme Court shall have original Jurisdiction." 170 First, note that although Supreme Court original jurisdiction extends to "all" ambassador cases, it does not explicitly extend to "all" lawsuits in which a state shall be party. Once again, this fact, taken alone, hardly seems conclusive; but once again, language of adjoining passages casts additional light. The carefully selective use of the word "all" in the Article III jurisdictional menu should make us specially sensitive to its use-and nonuse-later in that Article. ${ }^{171}$ Records of the Philadelphia Convention confirm the care with which the word "all" was used by the framers in Article III. A penultimate draft Constitution authored by the Committee of Style had omitted the word "all" from the enumeration of Supreme Court original jurisdiction; that one word was later added before the word "cases," which modifies the Ambassador Clause, but not before the words "those in which a state shall be party."172

But could it not be argued that the referent of the word "those" is "all cases" rather than "cases"? Perhaps, but this argument encounters several major obstacles. First, it is a strained reading of the text. If the word "those" had been omitted altogether, or if the text had spoken of "all those" cases in which a state shall be party, then the argument would be plausible enough, but of course the text does not say either of these things. The single word "those" stubbornly says too much and too little to support the idea that the Court has original jurisdiction in "all cases"

170 US Const, Art III, § 2, cI 2.

${ }^{171}$ See Amar, 65 BU L Rev at 242 (cited in note 12).

172 Compare 2 Farrand at 576 (cited in note 114) (Committee of Style draft) with id at 661 (final draft of Constitution). See generally Amar, 65 BU L Rev at 242-43 (cited in note 12). 
in which a state shall be party. ${ }^{173}$

Second and more fundamentally, the Original Jurisdiction Clause must be read in conjunction with the earlier enumeration in the jurisdictional menu. The "all cases" reading of the state party clause would, taken alone, seem to mean that the Supreme Court has original jurisdiction in a purely state law case brought by a state against its own citizens. Yet that surely cannot be right, for such a case does not even fall within the Article III jurisdictional menu, which limits the "judicial power" to only nine categories of "Cases" and "Controversies" that federal courts may (and in some cases must) hear.

The centrality of the enumeration in the jurisdictional menu is confirmed by the very language of the clauses distributing original and appellate jurisdiction. The ambassador language of the Original Jurisdiction Clause is painstakingly in haec verba with the earlier language from the jurisdictional menu; ${ }^{174}$ and, as we shall see below, the state party language of the Original Jurisdiction Clause was designed simply to incorporate by reference three state-diversity categories in the jurisdictional menu. ${ }^{175}$ The menu's incorporation by reference is even more explicit in the appellate jurisdiction language about "all the other cases before mentioned."

But once we keep in mind the centrality of the jurisdictional menu it becomes clear that even if the Supreme Court does have original jurisdiction over "all" cases in which a state shall be party, that jurisdiction is itself qualified by the language of the menu. And the menu pointedly fails to require federal jurisdiction over "all" state-diversity cases, in sharp contrast to its treatment of mandatory tier cases-that is, ambassador, arising under, and admiralty cases.

Yet even if the judicial power of the United States-and therefore the original jurisdiction of the Supreme Court-need not extend to all state-diversity cases, why is Congress, rather than the judiciary, empowered to decide which, if any, such cases shall be heard in federal courts? The short answer is the explicit language of Article I, § 8: "Congress shall have Power . . . To make all Laws which shall be necessary and proper for carrying into Execution

${ }^{173}$ Nevertheless, the Supreme Court has at times obscured this point through careless use of ellipses. See, for example, Ohio v Wyandotte Chem. Corp., 401 US 493495 (1971) (quoting sentence thus: "In all cases . . . in which a state shall be Party, the supreme Court shall have original Jurisdiction").

${ }^{174}$ See US Const, Art III, $\S 2$, cl 1 (referring to "all Cases affecting Ambassadors, other public Ministers and Consuls"); id cl 2 (in haec verba).

${ }^{175}$ See section V. 
the foregoing Powers, and all other Powers vested by this Constitution in the Government of the United States, or in any Department or Officer thereof." 178 Although ever since $\mathrm{McCulloch} v \mathrm{Ma}$ ryland, ${ }^{177}$ scholars have tended to focus only on the federalism implications of this clause, its language also has obvious implications "horizontally," as Professor Van Alstyne's work has emphasized. ${ }^{178}$

Let me be clear: I am not arguing that the clause empowers Congress to do anything it wants to the federal courts. Here, as elsewhere, Congress's power is limited by other language in the Constitution, including Article III. ${ }^{179}$ For example, Congress has no authority under the Necessary and Proper Clause to disregard the Article III mandate that the judicial power of the United States shall be vested in a federal judiciary, and shall extend to all mandatory tier cases. But within the parameters established by the words and spirit ${ }^{180}$ of Article III, Congress has significant authority under the Necessary and Proper Clause to structure the federal judiciary. This argument is hardly a novel one, used only to paper over a possible crack in the two-tiered thesis. Rather, it is one of several basic principles underlying Article III. ${ }^{181}$ How many Supreme Court justices shall there be? What procedural rules should the Court follow in original jurisdiction cases? When shall the Court sit? Article III does not say, nor is there any specific language in Article III itself empowering Congress to decide those questions. Yet no one doubts that those decisions are Congress's to make, under the plain language of the Necessary and Proper Clause. ${ }^{182}$ So too with the precise scope of federal jurisdiction over (not necessarily all) "controversies between two or more States;--between a State and Citizens of another State; . . . and between a State . . . and foreign States, Citizens or Subjects."183

Thus, Congress gets its power to restrict Supreme Court origi-

${ }^{178}$ US Const, Art I, § 8, cl 18 (emphasis added).

17717 US (4 Wheat) 316 (1819).

${ }^{178}$ See William W. Van Alstyne, The Role of Congress in Determining Incidental Powers of the President and of the Federal Courts: A Comment on the Horizontal Effect of the Sweeping Clause, $40 \mathrm{~L} \&$ Contemp Probs 102 (Spring 1976).

179 See, for example, Amar, 65 BU L Rev at $229 \mathrm{n} 84$ (cited in note 12).

180 See id at $267 \&$ n 206. See also Amar, 96 Yale L J at 1518-19 (cited in note 27) (discussing congressional pretext). See generally $\mathrm{McCulloch}, 17$ US (4 Wheat) at $421,423$.

${ }^{181}$ See Amar, 96 Yale L J at 1443 n 71 (cited in note 27).

182 See, for example, Wayman $v$ Southard, 23 US (10 Wheat) 1, 21-22 (1825) (Marshall for the Court) (expressly relying on language of Necessary and Proper Clause to uphold power of Congress to legislate process rules for federal courts).

${ }^{183}$ US Const, Art III, § 2, cl 1. 
nal jurisdiction from the two-tiered language of the jurisdictional menu of Article III, § 2, read in light of the Necessary and Proper Clause of Article I. Congress receives no additional power to restrict Supreme Court original jurisdiction from the Original Jurisdiction Clause itself. So once Congress decides to extend federal jurisdiction to state-diversity cases, the Original Jurisdiction Clause will demand that the Supreme Court "shall" have original jurisdiction over "those" state party cases (where the absence of the word "all" only reaffirms the congressional power under the jurisdictional menu) to which Congress has decided to extend federal jurisdiction. This approach also explains the importance of the Exceptions Clause to the appellate jurisdiction power. Once Congress, using its necessary and proper power, decides how far to extend federal jurisdiction beyond the mandatory tier of jurisdiction, the Exceptions Clause then gives it the additional power to take cases from the Supreme Court's appellate jurisdiction and provide instead for unreviewable jurisdiction in inferior federal courts. ${ }^{184}$

\section{B. Early Case Law}

Thus far, I have argued that congressional power to restrict Supreme Court original jurisdiction over state party cases is supported by a close reading of the words of the Original Jurisdiction Clause, the jurisdictional menu, and the Necessary and Proper Clause. Elsewhere, I have argued that the overall history and twotiered structure of Article III confirm this reading. ${ }^{185} \mathrm{I}$ shall now show that this reading is also supported by early nineteenth century case law.

The most prominent judicial exposition of the two-tiered thesis, of course, appears in Justice Joseph Story's landmark opinion in Martin $v$ Hunter's Lessee; ${ }^{186}$ but this exposition finds strong echoes in subsequent opinions authored by Chief Justice Mar-

1s4 Congressional power over federal courts thus reflects several distinct structural patterns. At one end, congressional power to create lower federal courts is granted by specific language in both Article I and Article III. US Const Art I, § 8, cl 9; id Art III $\S 1$. At the other end, congressional power to shift the last word on cases within the judicial power from the Supreme Court to some lower federal court derives only from a grant of power in Article III itself, in the Exceptions Clause. Congressional power over Supreme Court original jurisdiction in state party cases reflects yet a third pattern between these two extremes, resting on the interplay of the general language of the Necessary and Proper Clause of Article I with the two-tiered language of the jurisdictional menu and Original Jurisdiction Clause of Article III.

185 See generally Amar, 65 BU L Rev 205 (cited in note 12).

186 US (1 Wheat) 304, 327-52 (1816). See generally Amar, 65 BU L Rev at 210-15, 218 (cited in note 12) (discussing Martin). 
shall, ${ }^{187}$ and in extra-judicial writings of both Story $^{188}$ and Marshall. ${ }^{189}$

For our narrow purposes here, however, the most important Court statement appears not in the two-tiered language of the Marshall Court-language appearing only in federal question cases on the Court's appellate docket-but in a rather obscure Taney Court case in which the Court sat in original jurisdiction, Rhode Island $v$ Massachusetts. ${ }^{190}$ At oral argument, counsel for defendants placed considerable emphasis on the two-tiered thesis:

It is to be observed, that the word "all," which is prefixed to the other classes of cases, is here omitted. The judicial power extends to all cases under the laws of the United States; all cases under the treaties made, \&c.; all cases affecting ambassadors, \&c; all cases of maritime and admiralty jurisdiction; but its phraseology is changed, and the universality limited by the omission of the word "all," when it relates to controversies ... between two or more states. The judicial power, then, does not reach all possible controversies ... between two or more states. ${ }^{191}$

Counsel went on to urge that this two-tiered language of its own force authorized the Court to decline to hear the particular case at bar. Listen carefully to the Court's reply:

[T] he constitution does not, in terms, extend the judicial power to all controversies between two or more states. ... It was necessarily left to the legislative power to organize the Supreme Court, to define its powers consistently with the constitution, as to its original jurisdiction. ... In obedience to the injunction of the constitution, congress exercised their power, so far as they thought necessary and proper, under the seventeenth [sic] clause of the eighth section, first article, for carry-

${ }^{187}$ See, for example, Cohens $v$ Virginia, 19 US (6 Wheat) 264, 378 (1821) (quoted in text at note 216); American Insurance Co. v Canter, 26 US (1 Pet) 511, 545 (1828).

188 Story, 3 Commentaries $\$ 1696$ at 573 (cited in note 124) ("But it is clear, from the language of the constitution, that, in one form or the other, it is ahsolutely obligatory upon congress, to vest all the jurisdiction in the national courts, in that class of cases at least, where it has declared, that it shall extend to "all cases'") (emphasis in original).

280 John Marshall, A Friend of the Constitution, in Gerald Gunther, ed, John Marshall's Defense of McCulloch v Maryland 213-14 (Stanford, 1969) (distinguishing between class of cases dependent on "the character of the cause" from class dependent on "the character of the parties"); id at 204 (federal question jurisdiction "stood first in the mind of the framers of the Constitution").

10037 US (12 Pet) 657 (1838):

101 Id at $672-73$. 
ing into execution the powers vested by the constitution in the judicial, as well as all other departments and officers of the government of the United States. ${ }^{182}$

Today's Supreme Court seems to have forgotten the lessons-and the language-of Martin and Massachusetts. Thus, Justice O'Connor recently cited Martin for the proposition that Congress has no authority to withdraw original jurisdiction from the Court in state party cases. ${ }^{193}$ Yet the language of Martin at the page she cites most emphatically says nothing of the kind:

It is declared that "in all cases affecting ambassadors, \&c., that the supreme court shall have original jurisdiction." Could congress withhold original jurisdiction in these cases from the supreme court? ${ }^{194}$

Story carefully avoids mentioning state party cases in this passage, and focuses only on "all cases affecting ambassadors, \&c." Of course, were it not for the rest of his opinion in Martin, we might be justified in assuming that Story's "\&c." referred to all the remaining words in the Original Jurisdiction Clause, including those concerning state party cases. But other passages in Martin sharply distinguish between all ambassador, arising under, and admiralty cases on the one hand, and the six other party defined categories of controversies on the other. ${ }^{195}$ In light of these passages, Story's subtle refusal in the above quoted passage to lump together ambassador and state party cases seems obviously intentional.

Justice O'Connor's misreading of Martin is paralleled by, and reflective of, her general misreading of the structure of Article III. Under her vision, there are indeed two tiers of federal jurisdiction, but the tiers map onto, rather than cut across, the distinction between the Supreme Court's original and appellate jurisdiction. ${ }^{196}$ Under her vision, because original jurisdiction cases involve "sovereign" states, they may not be withdrawn from the Court by Congress, even in favor of lower federal court jurisdiction. ${ }^{197}$ By contrast, Congress may shift appellate jurisdiction cases, including those in the all-important federal question category, away from all federal courts thus leaving the courts of "sovereign" states with the

192 Id at 721 .

193 South Carolina v Regan, 465 US 367, 397 (O'Connor concurring in judgment).

194 Martin, 14 US (1 Wheat) at 332 (emphasis added by Story).

195 Id at $333-36,339,347$.

196 See Regan, 465 US at 396 (O'Connor concurring in judgment).

197 Id at $396-97$. 
last word. ${ }^{188}$ Justice $O^{\prime}$ Connor declares that this vision of Article III reflects "respect" for "federalism" and "sovereignty."188

Justice Story had a very different vision of federalism and sovereignty-a vision emphasizing popular sovereignty, not state sovereignty, ${ }^{200}$ and a brand of federalism in which federal courts stand as irreplaceable guardians of constitutional rights against states. ${ }^{201}$ Under Story's two-tiered model, state party cases that involve no federal questions are nothing special, and could even be excluded altogether from federal courts. Story would no doubt note that if Justice O'Connor sees state party cases as particularly momentous, it is simply because those cases do often involve important constitutional issues, rather than because of their mere party alignment per se. ${ }^{202}$ Indeed, if Justice O'Connor could imagine a state party case in which no federal question existed-say a simple contract dispute in which each state was just an assignee under a contract initially made by two private parties-would she not see such a case as qualitatively less important than cases arising under the Constitution, even if only involving private parties?

Nor is the inclusion of state party cases in the Supreme Court's original jurisdiction a sign of their Article III centrality, as

${ }^{298}$ Id.

${ }^{109}$ Id at 397. For an earlier exposition of this same view, see Sandra D. O'Connor, Trends In the Relationship Between the Federal and State Courts from the Perspective of a State Court Judge, 22 Wm \& Mary L Rev 801, 815 (1981) ("The jurisdiction of state courts to decide federal constitutional questions cannot be removed by congressional action, whereas the federal court jurisdiction can be shaped or removed by Congress.") (citing $E x$ Parte McCardle, 74 US (7 Wall) 506 (1869); Sheldon v Sill, 49 US (8 How) 440 (1850)). Then-Judge O'Connor errs on both counts. First, Congress most assuredly does have authority to oust state court jurisdiction by providing for exclusive federal court jurisdiction in all federal question cases. See The Moses Taylor, 71 US (4 Wall) 411, 428-31 (1867); Cohens, 19 US (6 Wheat) at 397. Second, Congress does not have plenary authority over federal question cases, as Justice O'Connor implies. See generally Amar, 65 BU L Rev 205 (cited in note 12). It simply will not do to chant "McCardle" and "Sheldon." For the precise question is not whether Congress can make exceptions to the Court's appellate jurisdiction (it can), or whether Congress can strip lower federal courts of jurisdiction (it can do this too), or even whether it can do both at the same time (it can even do this, for diversity cases), but whether it can leave state courts with the last word on federal constitutional questions. And neither McCardle, nor Sheldon, nor both of them together speak to this question. Martin does. Compare Amar, 102 Harv L Rev at 713-14 (cited in note 39).

${ }^{200}$ See generally Amar, 96 Yale L J 1425 (cited in note 27).

${ }^{201}$ See generally Amar, $65 \mathrm{BU}$ L Rev at 210-19 (cited in note 12).

${ }^{202}$ Of course state party cases that also raise federal questions fall within the mandatory tier, and thus some federal court must be open, at least on appeal, to resolve such cases. Most cases involving especially sensitive state interests would raise federal questions; in most border dispute cases between state "sovereigns," for example, the question of which state's law should apply can itself be seen as a federal question under the Full Faith and Credit Clause, US Const, Art IV, § 1. Compare Amar, 96 Yale L J at 1474 n 202 (cited in note 27 ). 
Justice O'Connor implies. As we have seen, these cases may be heard in the first instance by the Supreme Court for reasons largely geographic. ${ }^{203}$ Although state-diversity cases per se need not be heard by any federal court, if they are to be heard, Congress must allow them to be tried in the Supreme Court, which serves as a purely neutral Article III court outside the geographic territory of either state. ${ }^{204}$

Now, I have been rather unfair to Justice O'Connor by singling out her disregard of Justice Story's vision of Article III. In this (dis)regard Justice O'Connor is in very good company. Following the lead of Professor Henry Hart, several leading scholars of federal jurisdiction assert broad congressional authority to give state courts the last word in federal question cases even as these same scholars deny Congress the power to restrict the Supreme Court's original jurisdiction. ${ }^{205}$ (Why they are willing to acknowledge the mandatory force of the words "shall" and "all" in the Original Jurisdiction Clause, but not in Article III, $\S 1$ and the jurisdictional menu, these scholars do not say.) Yet the doctrines of the "Hart School" have not gone unchallenged. On the contrary, another, equally distinguished group of modern federal jurisdiction scholars has arisen to counter the Hart School's reading of Article III with a constitutional vision more akin to Joseph Story's, a vision emphasizing the centrality of federal question cases, and the parity of federal judges. ${ }^{208}$ Although the debate has heretofore focused almost exclusively on congressional power under the Exceptions Clause to regulate appellate jurisdiction, I hope I have shown that the Original Jurisdiction Clause can cast additional light on these issues.

Indeed, precisely because it implicates the two-tiered nature of federal jurisdiction, and the structural parity of federal judges, my reading of the Original Jurisdiction Clause here ramifies into a wide assortment of doctrinal debates among modern day federal

203 See text at notes 126-62.

204 Compare Amar, 65 BU L Rev at 221 n 60 (cited in note 12). Congress may also provide for concurrent jurisdiction in the state courts or in inferior federal courts. See note 219 .

200 See, for example, Henry M. Hart, Jr., The Power of Congress to Limit the Jurisdiction of Federal Courts: An Exercise in Dialectic, 66 Harv L Rev 1362, 1372-73, 1401 (1953); Redish, Federal Jurisdiction at 12 (cited in note 99); Martin H. Redish, Congressional Power to Regulate Supreme Court Appellate Jurisdiction under the Exceptions Clause: An Internal and External Examination, 27 Vill L Rev 900, 901, 906-24 (1982).

${ }^{208}$ See, for example, Sager, 95 Harv L Rev 17 (cited in note 115); Clinton, $132 \mathrm{U}$ Pa L Rev 741 (cited in note 52). My own scholarship also falls in this camp. See generally Amar, 65 BU L Rev 205 (cited in note 12). 
jurisdiction scholars-debates over the appropriate scope of various abstention doctrines, over the optimal contours of federal question jurisdiction, over the preclusive effect of state court determinations in federal court, and over the proper scope of federal habeas corpus review, to name just a few. ${ }^{207}$

Yet another doctrinal debate in the pages of today's law reviews and case reporters concerns the meaning of the Eleventh Amendment. As we shall see below, the Original Jurisdiction Clause has quite interesting and specific implications for this debate. To see those implications, let us turn to our fourth and final question about original jurisdiction.

V. Fourth Question: Do "Cases ... In which a State shall Be Party" Encompass More Than the Three State-Diversity Categories of the JuRisdictional Menu?

Thus far, I have argued that Congress may not add to the Supreme Court's original jurisdiction beyond the ambassador and state party language of Article III itself, but that Congress may, by withdrawing all federal jurisdiction over state party cases, also withdraw the Court's original jurisdiction over "those [cases] in which a state shall be party." But precisely which cases fall within this quoted language? Unlike the ambassador language of the Original Jurisdiction Clause, which carefully repeats the words of the jurisdictional menu, or the language of the Appellate Jurisdiction Clause, which simply refers to "before mentioned" cases without more, the State Party Clause uses language that does not echo the jurisdictional menu.

One conceivable reading would be to allow original jurisdiction whenever a state is party. Yet, as we have seen, ${ }^{208}$ this autistic reading of the clause cannot be right, for it would extend Supreme Court original jurisdiction beyond the jurisdictional menu-for example, to purely state law suits brought by a state against its own citizens. The problem with this reading is not so much that it is "literal" as that it is mindlessly and selectively literal, for it ignores other central words of Article III, namely, the jurisdictional menu, which defines and limits the scope of the "judicial Power" of the Unites States.

${ }^{207}$ For two recent and thoughtful analyses of these interconnected doctrinal debates, see Erwin Chemerinsky, Parity Reconsidered: Defining a Role for the Federal Judiciary, 36 UCLA L Rev 233 (1988); Richard H. Fallon, Jr., The Ideologies of Federal Courts Law, 74 Va L Rev 1141 (1988).

${ }^{208}$ See text at notes $173-74$. 
Once we properly recognize that "those cases in which a state shall be party" must refer to only a subset of the nine categories of cases and controversies spelled out in the menu, two possibilities remain. First, the clause could be read to authorize original jurisdiction in any of the nine categories whenever a state happened to be a party. Under this "literal" reading, for example, a federal question suit brought by a state against its own citizen would fall within the Court's original jurisdiction. Second, the clause could be read simply to allow original jurisdiction only where the suit falls within the menu because the state is a party-i.e., only where the lawsuit is one "between two or more States;-between a State and Citizens of another State; .. . [or] between a State . . . and foreign States, Citizens or Subjects." Under this "state-diversity" reading, a federal question suit by a state against its own citizens could not be brought originally in the Supreme Court, although that Court could hear the case on appeal.

In light of the foregoing analysis of the Original Jurisdiction Clause, the "diversity" reading seems plainly superior. Although the "literal" reading might seem to reflect better the actual text of the Original Jurisdiction Clause, we have seen that that clause cannot be examined in isolation-otherwise we would be led into the obvious error of the "autistic" reading. And once we consult the Article III menu-as we must if we reject the "autistic" reading-we find a fundamental distinction between mandatory tier cases defined by subject matter of lawsuits and permissive tier cases defined by party status. In light of this distinction, it makes most sense to see the state party language of the Original Jurisdiction Clause as simply referring to the three party-defined categories where jurisdiction depends on a state's party status.

The "diversity" reading also best comports with the geographic logic underlying the allocation of original jurisdiction between the Supreme Court and other courts. Unlike state-diversity cases, where the parties will come from different geographic regions and a court in the nation's capital can provide a neutral geographic forum, a federal question case between a state and its own citizens seems obviously to call for a trial within the geographic confines of that state. If state courts are not deemed sufficiently trustworthy in these cases, Congress has full power to institute inferior federal courts, within the state, to hear such cases. ${ }^{209}$ To in-

${ }^{200}$ The same is true of suits between a state and the United States. But see United States v Texas, 143 US 621 (1892), discussed at note 217. 
vite Congress to "drag" both parties "to the centre"210 for trial in the Supreme Court seems a perversion of the basic geographic vision animating Article III.

Furthermore, only the diversity reading meshes well with the criminal venue provisions of Article III. If a Massachusetts resident commits acts within that state that give rise to a federal prosecution, and to which he asserts a federal defense, Article III would require the federal government to hold the trial within Massachusetts. ${ }^{211}$ It would be odd (to say the least) if that same Article were read to encourage the federal government to drag the parties hundreds of miles away for trial in the Supreme Court if the defendant were civilly prosecuted by the Massachusetts government for similar acts, to which the defendant asserted a similar federal defense.

Further support for the "diversity" thesis comes from our old friend, $\S 13$ of the Judiciary Act of 1789. For although Congress nowhere else attempted to effect sweeping restrictions on the Court's original jurisdiction, ${ }^{212}$ it expressly disallowed suits "between a state and its citizens." 13 The most plausible inference that can be drawn is that the first Congress apparently did not deem such cases, even if they presented federal question or admiralty issues, as being encompassed by the "those in which a State shall be Party" language of Article III.

Marshall Court case law also endorses the "diversity" reading. In Cohens $v$ Virginia, ${ }^{214}$ a federal question case brought by a state against its own citizens in state court, Virginia argued that the Supreme Court lacked Article III appellate jurisdiction because: (1) the suit was one to which a state was party, and thus, under a "literal" reading of the State Party Clause, within the Supreme Court's original jurisdiction; and (2) under a "literal" reading of the Appellate Jurisdiction Clause, the Court had appellate jurisdiction only in cases "other" than those in which it had original jurisdiction. ${ }^{215}$

Chief Justice Marshall's landmark opinion for the Court rejected both "literal" readings. Marshall began by discussing the words, and the two-tiered structure, of the Article III menu:

210 See text at note 138.

211 US Const, Art III, § 2, cl 3 .

212 But see Amar, 65 BU L Rev at 261 n 183, 264-65 n 194 (cited in note 12) (noting small ways in which $\S 13$ might be less extensive than original jurisdiction language of Article III).

${ }^{213}$ Judiciary Act of 1789 , ch $20, \S 13,1$ Stat 73,80 (quoted in text at note 54).

21419 US (6 Wheat) 264 (1821).

21 Id at 300-01. 
The second section of the third article of the constitution defines the extent of the judicial power of the United States. Jurisdiction is given to the courts of the Union, in two classes of cases. In the first, their jurisdiction depends on the character of the cause, whoever may be the parties. This class comprehends "all cases in law and equity arising under this constitution, the laws of the United States, and treaties made, or which shall be made under their authority." . . .

In the second class, the jurisdiction depends entirely on the character of the parties. In this are comprehended "controversies between two or more states, between a state and citizens of another state," and "between a state and foreign states, citizens or subjects." 216

After several pages of close analysis, Marshall emphatically embraced the "diversity" reading, and explicitly rejected Virginia's "literal" reading of the Original Jurisdiction Clause, largely in reliance on the two-tiered nature of the menu:

[T] he original jurisdiction of the supreme court, in cases [sic] where a state is a party, refers to those cases in which, according to the grant of power made in the preceding clause, jurisdiction might be exercised, in consequence of the character of the party. ${ }^{217}$

This alone would have sufficed to answer Virginia's argument, for if the Supreme Court did not have Article III original jurisdiction over the case, then it could entertain an appeal even under Virginia's "literal" reading of the Appellate Jurisdiction Clause, which denied that the Court could ever assert appellate jurisdiction over a case within its Article III original docket. Yet Marshall went on to reject Virginia's second "literal" argument as well.

Imagine, Marshall explained, a case in which a state sued a citizen of a different state, and which also arose under federal

216 Id at 378. Marshall viewed "all Cases affecting Ambassadors" as defined by "the character of the cause" and not "the character of the parties" (emphasis added). See Osborn $v$ Bank of the United States, 22 US (9 Wheat) 738, 855 (1824); Marshall, A Friend of the Constitution at 213-14 (cited in note 189); Amar, 65 BU L Rev at 246 n 132 (cited in note 12). Thus, Marshall's two tiers in Cohens correspond precisely with Story's in Martin.

${ }^{217}$ Id at 398. See also id at 393-94 (Supreme Court has original jurisdiction in "those cases, in which jurisdiction is given, because a state is a party").

The words of Cohens, along with the textual, structural, and geographic arguments presented above, suggest that the Court later erred in upholding its original jurisdiction in a suit between the United States and a state (United States $v$ Texas, 143 US 621 (1892)), and that 28 USC $\S 1251$ (b)(2) (1982), giving the Court original jurisdiction in such a suit, is unconstitutional. 
law. ${ }^{218}$ Even under the "diversity" reading of the Original Jurisdiction Clause, the Supreme Court could try the case, if Congress so desired. But suppose Congress withdrew all federal jurisdiction over state-diversity cases (and thus Supreme Court original jurisdiction as well), or made the Supreme Court's original jurisdiction concurrent with the state courts'. ${ }^{219}$ Would the language of the Appellate Jurisdiction Clause allow the Supreme Court to hear the case on appeal, as part of its general federal question appellate docket?

Virginia argued that the literal words of Article III forbade such a result by extending Supreme Court appellate jurisdiction only to cases "other" than those to which Article III gave original jurisdiction. But Marshall insisted that this language could not be examined in isolation, but only as part of the larger structure of Article III. Once again, Marshall turned to the two-tiered nature of the menu, in which mandatory tier cases were to be heard because of the "nature" of their subject matter, whereas permissive tier cases were to be heard because of the "nature" of their party configurations. ${ }^{220}$ Although the Court should perhaps not be allowed to entertain appeals simply on the basis of a state-diversity configuration, surely it should not be barred by that configuration from hearing an appeal on the basis of the federal questions involved:

The constitution declares, that in cases where a state is a party, the supreme court shall have original jurisdiction; but does not say, that its appellate jurisdiction shall not be exer-

218 Cohens, 19 US (6 Wheat) at 392-93.

219 Nothing in the explicit language or the geographic logic of Article III seems to prevent Congress from opting for original jurisdiction concurrent with the state courts, at least in state party cases. Compare Amar, 65 BU L Rev at $261 \mathrm{n} 183$ (cited in note 12) (discussing problems posed by state court concurrent jurisdiction in ambassador cases). Section 13 of the Judiciary Act provided for concurrent jurisdiction with the lower federal courts in certain situations, and in 1793 Circuit Justice Wilson and Judge Peters upheld this grant of jurisdiction. United States v Ravara, 2 US (2 Dall) 297, 298 (Cir $\mathrm{Pa}$ 1793). Justice Iredell dissented, id at 298-99 (Iredell dissenting); but see Chisholm v Georgia, 2 US (2 Dall) 419, 436 (1793) (opinion of Iredell) (implying permissibility of original jurisdiction concurrent with both federal lower courts and state courts). Later dicta from the Supreme Court muddied the waters, but the Court eventually upheld concurrent jurisdiction with the lower federal courts in two 1884 cases, Börs v Preston, 111 US 252, 256-61 (1884); Ames v Kansas ex rel. Johnston, 111 US 449, 463-71 (1884). See generally Wienczyslaw J. Wagner, The Original and Exclusive Jurisdiction of the United States Supreme Court, 2 SLU L J 111 (1952). If other courts are given concurrent jurisdiction in state party cases, the "supremacy" of the Supreme Court may well mean that the Court should be seen as having implied power under Article III to remove any of these cases to itself at the request of defendant (who did not choose the concurrent forum). Compare Amar, 65 BU L Rev at $221 \mathrm{n} 60,261 \mathrm{n} 183$ (cited in note 12).

${ }^{220}$ Cohens, 19 US (6 Wheat) at 393. 
cised in cases where, from their nature, appellate jurisdiction is given, whether a state be or be not a party. ${ }^{221}$

Thus Marshall read both the Original and Appellate Jurisdiction Clauses in the strong light of the two-tiered nature of the menu, summing up his position as follows:

When, then, the constitution declares the jurisdiction, in cases [sic] where a state shall be a party, to be original, and in all cases arising under the constitution or a law, to be appellate, the conclusion seems irresistible, that its framers designed to include in the first class those cases in which jurisdiction is given, because a state is a party; and to include in the second, those in which jurisdiction is given, because the case arises under the constitution or a law. ${ }^{222}$

Marshall's analysis in the above quoted passages is compelling. Especially significant is his forceful rejection of Virginia's second "literal" argument, an issue he reached out to decide. For if this reading had been allowed to take root, a major hole in the mandatory tier would have been opened up, allowing state courts to serve as the last word in federal question cases simply because of the happenstance of party configuration.

Yet this is precisely the result that another Marshall-Professor Larry Marshall of Northwestern Law School-has argued for in a recent article in the Harvard Law Review. ${ }^{223}$ Professor Marshall's new argument is an eerie echo, both substantively and methodologically, of Virginia's second "literal" argument in Cohens. Professor Marshall's argument, however, is based not on the language of the Appellate Jurisdiction Clause, but on that of the Eleventh Amendment.

That amendment, it will be recalled, was passed in response to one of the first, and one of the most famous (second only to Marbury itself), $\S 13$ cases ever adjudicated by the Court-Chisholm $v$ Georgia. ${ }^{224}$ As a pure state-diversity assumpsit case brought by a citizen of South Carolina against Georgia, Chisholm fell squarely within the original jurisdiction language of both Article III and § 13. It must be stressed that Chisholm was not an "arising under" case-plaintiff nowhere claimed that defendant had violated any

221 Id at 395. Accord Story, 3 Commentaries $\S 1702$ at 578 (cited in note 124).

222 Cohens, 19 US (6 Wheat) at 393-94.

${ }^{223}$ Lawrence C. Marshall, Fighting the Words of the Eleventh Amendment, $102 \mathrm{Harv}$ L Rev 1342 (1989).

2242 US (2 Dall) 419 (1793). 
federal statutory, constitutional, or treaty-based norm. ${ }^{225}$ After properly asserting original jurisdiction over the case, however, the Court proceeded to opine that Georgia could be held liable on the merits, ${ }^{228}$ thereby disregarding the common law immunity of Georgia, even though such immunity was recognized at the time by virtually every state, including, it seems, both Georgia and South Carolina. ${ }^{227}$ By suggesting that Georgia was liable on general federal common law principles, the Court threatened to wreak havoc with state fiscs, even where states had faithfully followed all applicable federal law.

Soon after Chisholm came down, an amendment was introduced to overrule the case. In its final form, it read as follows:

The Judicial power of the United States shall not be construed to extend to any suit in law or equity, commenced or prosecuted against one of the United States by Citizens of another State, or by Citizens or Subjects of any Foreign State. ${ }^{\mathbf{2 2 8}}$

Over the last century, the Supreme Court-inspired by a vision of federalism and sovereignty far closer to Justice O'Connor's than Justice Story's - has seen the amendment as enshrining states' general "sovereign" immunity from suit, ${ }^{229}$ even in cases obviously not addressed by any conceivable reading of the words of the amendment, such as federal question suits against one's own state, ${ }^{230}$ or admiralty cases, which are technically not suits in either law or equity, against a state. ${ }^{\mathbf{2 3 1}}$

In recent years, however, the "state sovereignty" theory of the Eleventh Amendment has been powerfully challenged by a group of scholars-more akin to Joseph Story-who have put forth a very different "diversity" reading of the amendment. ${ }^{232}$ Under this

${ }^{223}$ Amar, 96 Yale L J at 1470 \& nn 187, 188 (cited in note 27).

${ }^{228}$ See, for example, Chisholm, 2 US (2 Dall) at 465 (opinion of Wilson) ("on principles of general jurisprudence, a state, for the breach of a contract, may be liable for damages"); id at 466 (concluding words: "the action [for assumpsit] lies"); id at 469 (opinion of Cushing) ("I think assumpsit will lie, if any suit; provided a State is capable of contracting"). But see also id at 479 (opinion of Jay) (appearing to leave open the possibility of recognizing future substantive defenses raised by the state defendant).

${ }_{227}$ Amar, 96 Yale L J at 1474-75 n 202 (cited in note 27).

${ }_{228}$ US Const, Amend XI.

${ }^{229}$ Subject to a byzantine and ever changing edifice of doctrinal exceptions. See Amar, 96 Yale L J at 1473 \& $n$ 201, and at 1478-80 (cited in note 27 ).

${ }_{230}$ See, for example, Hans v Louisiana, 134 US 1, 9-13 (1890); Edelman v Jordan, 415 US 651, 662-63 (1974).

${ }^{231}$ See, for example, Ex parte New York, 256 US 490, 497-500 (1921).

${ }^{232}$ See, for example, John V. Orth, The Judicial Power of the United States (Oxford, 1987); William A. Fletcher, A Historical Interpretation of the Eleventh Amendment: $A$ 
reading, the amendment simply repealed the state-diversity grant at issue in Chisholm, but this repeal in no way ousts federal jurisdiction based on some other grant, such as federal question or admiralty. Under this reading, certain language of the amendment-citizens of another state" and "citizens or subjects of any foreign state"-reads virtually in haec verba with that of the statediversity clauses of the jurisdictional menu precisely because these and only these categories were meant to be repealed. And the text speaks only of "law and equity" cases precisely because this repeal was designed to leave all mandatory tier cases, including all admiralty cases, unaffected. The amendment is thus consistent with the framers' belief that federal question jurisdiction was more central than the diversity categories and with Justice Iredell's dissent in Chisholm, which sharply distinguished between federal question suits against states and mere state-diversity cases. ${ }^{233}$ The Supreme Court is currently evenly divided between the "state sovereignty" and the "diversity" readings, ${ }^{234}$ and has taken a case this Term in which it may very well decisively embrace one or the other. ${ }^{235}$

There things stood until Professor Marshall's recent article offering a third, "literal" reading of the amendment. ${ }^{236}$ Like the "diversity" theorists, Marshall argues that the amendment in no way bars admiralty suits against states, or federal question suits brought by a citizen against her own state. He thus believes that

Narrow Construction of an Affirmative Grant of Jurisdiction Rather than a Prohibition Against Jurisdiction, 35 Stan L Rev 1033 (1983); John J. Gibbons, The Eleventh Amendment and State Sovereign Immunity: A Reinterpretation, 83 Colum L Rev 1889 (1983); Vicki C. Jackson, The Supreme Court, the Eleventh Amendment, and State Sovereign Immunity, 98 Yale L J 1 (1988). My own scholarship is also in this tradition. See Amar, 96 Yale L J 1425 (cited in note 27).

${ }^{233}$ Chisholm, 2 US (2 Dall) at 432, 435-36. See also Amar, 96 Yale L J at 1472-73 (cited in note 27).

${ }^{234}$ Compare Atascadero State Hospital v Scanlon, 473 US 234, 237-47 (1985) (five member majority, including Chief Justice Burger and Justice Powell, embracing state sovereignty theory), with id at 258-90 (Brennan dissenting) (four member bloc endorsing diversity theory). See also Welch v Texas Dept. of Highways and Pub. Transp., $107 \mathrm{~S} \mathrm{Ct} 2941$, 2948-57 (1987) (four member plurality, including Justice Powell, embracing state sovereignty theory); id at 2957-58 (Scalia concurring in judgment on separate grounds); id at 2958-70 (Brennan dissenting) (four member bloc reaffirming diversity theory).

${ }^{23 s}$ United States v Union Gas Co., 832 F2d 1343 (3rd Cir 1987) cert granted sub nom, Pennsylvania v Union Gas Co., 108 S Ct 1219 (1988). [Editor's note: While this article was in press the Supreme Court affirmed the Third Circuit, see $109 \mathrm{~S} \mathrm{Ct} 2273$ (1989).

${ }^{236}$ While the current essay was in late draft, another thoughtful article, contemporaneous with and imdependent of Professor Marshall's, appeared in defense of the "literal" reading of the Eleventh Amendment. See Calvin R. Massey, State Sovereignty and the Tenth and Eleventh Amendments, 56 U Chi L Rev 61 (1989). For a brief response to Professor Massey's argument, see note 247. 
Hans $v$ Louisiana ${ }^{237}$ was wrongly decided. ${ }^{238}$ But unlike the diversity theorists, Marshall argues that the literal words of the amendment do bar federal question cases brought by a citizen against another state. ${ }^{238}$ As read by Marshall, the amendment thus constitutionalizes federal court discrimination against out-of-staters, in a perverse inversion of the Federalist Constitution's Diversity Jurisdiction and Privileges and Immunities Clauses; although a Louisianian can bring a federal question suit against his own state, an out-of-stater cannot, even if his substantive claim is identical. ${ }^{240}$

As a practical matter, there is little difference between Marshall and the diversity theorists, since most constitutional and other federal rights that a citizen enjoys are rights against her own, rather than another, state. Still the basically friendly debate between Marshall and the diversity theorists usefully illuminates deep questions of interpretive methodology. And the opinion of the Court in Cohens $v$ Virginia speaks to this debate with surprising precision. ${ }^{211}$

Professor Marshall argues that his reading is compelled by the "literal" words of the Eleventh Amendment. But similar "literal" arguments were made by Virginia in Cohens, and rejected by the Cohens Court. If the language- "the supreme Court shall have original Jurisdiction" in "those [cases] in which a State shall be Party" - can fairly be read to mean that the Court shall have original jurisdiction only in cases in which Article III jurisdiction exists because a state is a party, then surely the same is true for the lan-

${ }^{237} 134$ US I (1890).

${ }^{238}$ Marshall, 102 Harv L Rev at 1342-43 (cited in note 223).

${ }^{239}$ Id at 1346-47, 1362, 1367-71.

${ }^{240}$ To put the point doctrinally, Professor Marshall challenges the Court's decision in Hans but approves of the Court's dismissal of an earlier federal question case brought by a non-Louisianan, Louisiana v Jumel, 107 US 711 (1883). Prior to the Atascadero case, Justice Brennan appeared to subscribe to a "literal" interpretation of the Eleventh Amendment. See, for example, Hart \& Wechsler at 1167 (cited in note 33) (citing cases). It is perhaps indicative of the comparative persuasiveness of the "literal" and the "diversity" readings that when Justice Brennan switched to the "diversity" theory in Atascadero, he gained three converts.

${ }^{241}$ Admittedly, the Court in Cohens could have spoken to the Eleventh Amendment issue with even more precision. In addition to arguing that the Court lacked appellate jurisdiction under Article III, counsel for Virginia claimed that principles of federalism and sovereignty underlying the Eleventh Amendment also barred the Cohens' appeal. Cohens $v$ Virginia, 19 US (6 Wheat) 264, 305-09, 315 (1821). Counsel for the Cohens countered by explicitly putting forth the "diversity" reading of the Eleventh Amendment. Id at 348-49. Chief Justice Marshall overruled Virginia's Eleventh Amendment objections on narrower grounds, id at 405-12, passing up a perfect chance to apply his two-tiered analysis of Article III to the Amendment itself. But see Osborne $v$ Bank of the United States, 22 US (9 Wheat) 738, 798 (1824) (oral argument of Henry Clay). 
guage of the Eleventh Amendment: "The Judicial power of the United States shall not be construed to extend to any [state-diversity case brought by an out-of-stater against a state]" can be fairly read to mean that the judicial power shall not extend to those cases in which Article III jurisdiction existed because a state was a defendant and an out-of-stater a plaintiff. If the Original and Appellate Jurisdiction Clauses in Cohens are best read against the two-tiered backdrop of the jurisdictional menu, the same is true of the Eleventh Amendment. If it made little sense in Cohens to treat a state-diversity party configuration as creating a hole in the mandatory tier federal question jurisdiction, the same is true of the Eleventh Amendment.

Indeed, if anything, Virginia had a stronger "literal" argument in Cohens than Professor Marshall does for the Eleventh Amendment. First, major problems with Professor Marshall's literal argument emerge if we focus carefully (as he does not) on the words "be construed." The text of the amendment does not literally say that the judicial power shall not extend to any state-diversity suit, but only that such power shall not be construed to so extend. In fact these two words were initially omitted from the amendment's first draft, and were later added. ${ }^{242}$ Might these words support a reading that the judicial power shall not extend to certain statediversity cases as such, but could if supported by an independent jurisdictional basis, i.e., the presence of a federal question? As with our earlier $\S 13$ analysis of the word "power," the words "be construed" appear in other contexts that help illuminate their meaning. In an earlier essay on the Eleventh Amendment, I noted that the phrase "shall not be construed" also appeared in the Ninth Amendment, and in a way generally supportive of the "diversity" reading of the Eleventh. ${ }^{243}$ Yet Professor Marshall nowhere addresses the possible connection between the two amendments.

Also noteworthy, in 1807 Henry Clay introduced a constitutional amendment whose language carefully tracked that of the Eleventh: "The judicial power of the United States shall not be construed to extend to controversies between citizens of different states ...."244 Once again, Professor Marshall nowhere addresses the Clay amendment, but it raises some obvious problems for him. Would Professor Marshall read this proposed amendment to oust federal question cases in which the parties happened to come from

\footnotetext{
${ }^{242}$ Amar, 96 Yale $\mathrm{L} J$ at 1482 (cited in note 27).

243 Id at $1483 \& \mathrm{n} 234$.

244 Id at 1482 n 233 (citing 16 Annals of Cong 76 (1807)).
} 
different states? Wouldn't such a reading, even if "literal," be faithless to the obvious purport of Clay's amendment-the simple repeal of diversity jurisdiction?245 And if the phrase "shall not be construed" in the Clay amendment can bear a "diversity" reading, why can't the identical language in the Eleventh Amendment?

Last, we should not ignore another possible ambiguity in the phrase " $[t]$ he Judicial power . . . shall not be construed to extend to any suit ...." Does "not . . a any" mean that the judicial power shall not be construed to extend to even a single such suit, or might it instead mean that judicial power shall not be construed to extend to each and every such suit? Article III, of course originally extended jurisdiction to just any state-diversity suit, and the Eleventh Amendment can be "literally" read simply to say that henceforth, federal jurisdiction shall not extend to (just) any such suit. Without more, Professor Marshall's reading of "any" is perhaps more plausible, but without more, so was Virginia's argument in Cohens. Yet as in Cohens there is more, much more-the pointed omission of admiralty from the words of the Eleventh Amendment, ${ }^{246}$ other words of Article III and the structural vision underlying them, the logic of Iredell's dissent in Chisholm, and basic constitutional principles hostile to discrimination against out-ofstaters. Literalism is the beginning, and not the end, of the interpretive enterprise.

I have several other friendly quarrels with Professor Marshall's analysis, but these would take us far afield of my main purpose here-to show how the arguments put forth by Larry Marshall's recent article are in tension with those put forth by John Marshall's classic opinion in Cohens. Suffice it to say that I prefer the Chief's brand of Marshall law. ${ }^{247}$

245 See 16 Annals of Cong 216 (1807) (remarks of James Elliot).

${ }^{246}$ The diversity theory provides a unitary account explaining why the Eleventh Amendment is limited to out-of-state plaintiffs, and to cases in law or equity: precisely because only state-diversity suits were to be repealed, both federal question and admiralty cases were intended to be left untouched. By contrast, the "literalists" must tell one Rube Goldbergesque story about why the Amendment discriminated among federal question cases on the basis of the plaintiff's citizenship, see generally Marshall, 102 Harv L Rev 1342 (cited in note 223), and a second, wholly different, but equally roundabout story about why the Amendment omitted mention of admiralty. Professor Marshall cleverly attempts to downplay the problem by relegating the admiralty issue to a single footnote, id at $1355 \mathrm{n} 53$, but this tactic is more slick than satisfying. See also id at 1366 n 113, in which Professor Marshall again devotes only one footnote (perhaps because of space limitations) to an issue that is potentially devastating to the "literalist" reading-namely, the ability of out-of-state plaintiffs barred by literalism from federal courts to assign their claims to in-state plaintiffs.

${ }^{247}$ Nor am I ultimately persuaded by Professor Massey's intriguing essay in support of Eleventh Amendment "literalism." Massey, 56 U Chi L Rev 61 (cited in note 236). Unlike 


\section{Concluston}

No word is an island. None of the words that I have tried to parse with care (some would say "tediousness") here-_"power," "jurisdiction," "exceptions," "resort," "shall," "all," "those," "\&c," "construed,"and "any"-can be understood in isolation from its companions. None can be fully appreciated without an overall vision of the nature and purposes of federal jurisdiction. It is one such vision-inspired by Federalists like John Marshall and Joseph Story-that has served as the icing holding together the several sections of this birthday essay.

Professor Marshall, Professor Massey does invoke my argument that the words "be construed" bolster the "diversity" reading of the Amendment, especially in light of the proposed Clay Amendment of 1807. Yet like Professor Marshall, Massey provides no satisfactory answer to this argument; he simply asserts that the "literal" reading is preferable even though rendered "anomalous" by the Clay Amendment. Id at 118. But once it is conceded-as Massey appears to concede-that the words "be construed" are capable of bearing the meaning attributed to them by the "diversity" reading of the Eleventh Amendment, then the argument from "literalism" and "plain meaning" crumbles, and we are forced to look to the other words (such as the omission of admiralty, see note 246, and the language of Article III) and to constitutional structure to adjudicate between two plausible readings of "be construed." And once these sources are consulted, the diversity reading is far more powerful, coherent, and thus, plausible. Indeed, it is revealing that, like Professor Marshall, Massey nowhere even mentions my argument about the two-tiered structure of Article III, on which my Eleventh Amendment argument was explicitly premised. See Amar, 96 Yale L $J$ at 1483-84 \& $n 235$ (cited in note 27). Thus, Professor Massey is off base when he critiques my analysis by noting that "the theory of popular sovereiguty does not answer the jurisdictional question of which court system will hear claims against the states." Massey, $56 \mathrm{U}$ Chi $L$ Rev at 91 . I nowhere claimed it did, and indeed expressly asserted that it did not, Amar 96 Yale L J, at 1454. Thus, I elsewhere devoted nearly seventy pages to discussing the " $j u$ risdictional question" simpliciter. See generally Amar, 65 BU L Rev 205 (cited in note 12). Yet Massey never engages-or even shows his awareness of-the basic argument of these pages. In light of the undisputed fact that the Eleventh Amendment was favored by many "ardent nationalists," Professor Jacobs persuasively notes that it "seems clear" that "there was no real design, on the part of its framers, to effect a revolution in federal-state relations." Clyde E. Jacobs, The Eleventh Amendment and Sovereign Immunity 73, 92 (Greenwood, 1972). Compare Amar, 96 Yale L J at 1478 n 213, 1484, with Massey, 56 U Chi L Rev at $65,109 \mathrm{n} 254$. 


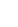

